University of South Florida

DIGITAL COMMONS

Digital Commons @ University of

@ UNIVERSITY OF SOUTH FLORIDA

South Florida

1989

\title{
The Wind-Driven Seasonal Circulation in the Southern Tropical Indian Ocean
}

Karen E. Woodberry

Mark E. Luther

Florida State University, mluther@usf.edu

James J. O'Brien

Follow this and additional works at: https://digitalcommons.usf.edu/msc_facpub

Part of the Life Sciences Commons

\section{Scholar Commons Citation}

Woodberry, Karen E.; Luther, Mark E.; and O'Brien, James J., "The Wind-Driven Seasonal Circulation in the Southern Tropical Indian Ocean" (1989). Marine Science Faculty Publications. 499.

https://digitalcommons.usf.edu/msc_facpub/499

This Article is brought to you for free and open access by the College of Marine Science at Digital Commons @ University of South Florida. It has been accepted for inclusion in Marine Science Faculty Publications by an authorized administrator of Digital Commons @ University of South Florida. For more information, please contact digitalcommons@usf.edu. 


\title{
The Wind-Driven Seasonal Circulation in the Southern Tropical Indian Ocean
}

\author{
KAREN E. WOODBERRY ${ }^{1}$, MARK E. LUTHER AND JAMES J. O'BRIEN
}

Mesoscale Air-Sea Interaction Group, Florida State University, Tallahassee

\begin{abstract}
A numerical model of the Indian Ocean, driven by climatological monthly mean winds, realistically simulates the major features of the large scale upper ocean circulation observed in the southem hemisphere and equatorial regions. The principal feature in the tropical Indian Ocean is a basin-wide clockwise southem hemisphere (cyclonic) gyre comprised of the South Equatorial Current to the south, the the South Equatorial Countercurrent to the north, and the East African Coastal Current in the west. Rossby waves propagate westward in the shear zone between the South Equatorial Current and the South Equatorial Countercurrent, and are obstructed and partially reflected by the banks along the SeychellesMauritius Ridge $\left(60^{\circ} \mathrm{E}\right)$. A region of high eddy activity northwest of Madagascar is an extension of the tropical gyre and is a tropical analog to the Gulf Stream recirculation region. Oscillations in meridional transport at the equator have westward phase speed and eastward group velocity and are the result of mixed Rossby-gravity (Yanai) waves forced by oscillations in the highly nonlinear westem boundary current region. Oscillations with 40- to 50-day periods are seen in most currents. These oscillations cannot be atmospherically forced, as the shortest period in the mean monthly wind forcing is 60 days. Mean transports in the western basin agree with observations. Small $(2 \mathrm{~Sv})$ mean throughflow from the Pacific to the Indian Ocean at the eastem open boundary is due to wind-forced Indian Ocean dynamics alone and is within the range of observations of throughflow from the Pacific.
\end{abstract}

\section{INTRODUCTION}

The expansive southern hemisphere oceans have been less studied than the smaller, more well-travelled oceans of the Northern Hemisphere. Large areas of the southern hemisphere oceans are relatively unexplored, resulting in a scarcity of both oceanographic and meteorological data. The Indian Ocean is a predominantly southern hemisphere ocean and data coverage is correspondingly thin. The efforts of the International Indian Ocean Expedition in 1962-1965 increased the oceanographic data available by a factor of 5 but emphasized the equatorial zone over southern regions [Wyrtki, 1971]. More recent efforts such as the FGGE (First GARP Global Experiment) Indian Ocean Experiment (INDEX) [see Schott, 1983; Swallow et al., 1983] and individual studies of Schott et al. [1988] and Swallow et al. [1988] have added to our knowledge of the westem portion of the basin, but on the whole, observational data remain sparse. We attempt herein to increase our understanding of this ocean through the use of a realistic wind-driven numerical model by comparing model fields with available observational data. Where agreement is found, th : model can be used to interpret the data in a wider context.

The Indian Ocean is interesting most obviously because of the seasonal monsoon reversals in winds and currents along the Somali Coast. Extensive observational effort has been focused on the northwest region, with relatively little attention paid to the southern subtropical circulation. A foundation is therefore lacking for understanding the effects of the southern hemisphere on the Somali Current and the equatorial regimes. Since much of the variability in the wind fields is found in the southern hemisphere [Hasienrath and

\footnotetext{
${ }^{1}$ Now at the Center for Atmospheric Theory and Analysis, University of Colorado, Boulder
}

Copyright 1989 by the American Geophysical Union

Paper number 89JC01511.

0148-0227/90/89JC-01511\$05.00
$L a m b, 1979]$, one might expect variability in the winddriven southern hemisphere circulation to be an important consideration. Indeed, Anderson and Moore [1979] show that changes in the southern hemisphere trade winds with the monsoons can affect the Somali Current north of the equator. Knowledge of the southern Indian Ocean is also necessary for understanding larger scale phenomena. Madden and Julian [1972] postulated an Indian Ocean source for observed 40- to 50-day atmospheric oscillations. Barnett [1983] investigated the interaction between Indian Ocean and Pacific Ocean winds and found strong coupling at interannual time scales and a strong connection to El Niño events in the Pacific. Nicholls [1984] found Indonesian sea surface temperature (SST) anomalies to lead Southem Oscillation and Pacific SST changes by about a season and suggested that interaction between ocean and atmosphere in the Indonesianorth Australia region may be a direct link between Indonesian SST and El Niño - Southern Oscillation (ENSO) events. As ENSO events are often viewed as perturbations of the seasonal cycle, it is important to understand the seasonal cycle of the circulation.

Numerical models have proven useful in studying the response of the ocean to changing wind, helping to integrate and interpret widely scattered observations. A comprehensive review of modelling efforts in the tropical Indian Ocean is given by Knox and Anderson [1985], in Knox [1987] and in Luther [1987]. Modelling of the Indian Ocean at the Florida State University, Tallahassee, has concentrated on the northwest (Somali Current) region of the Indian Ocean. We have recently extended the domain of the Luther and $O^{\prime} B r i e n$ [1985] model to cover the Indian Ocean to $25^{\circ} \mathrm{S}$. In this paper we describe the model simulation of the seasonal circulation in the southern hemisphere and compare it with available observations and theory.

The dominant feature of the observed southern hemisphere circulation is the subtropical gyre with the westward flowing South Equatorial Current (SEC) at $12^{\circ} \mathrm{N}$ as its northerm boundary (Figure 1 [Düing, 1970; Pickard and Emery, 1982]). The SEC splits at the coast of Madagascar into northward and 

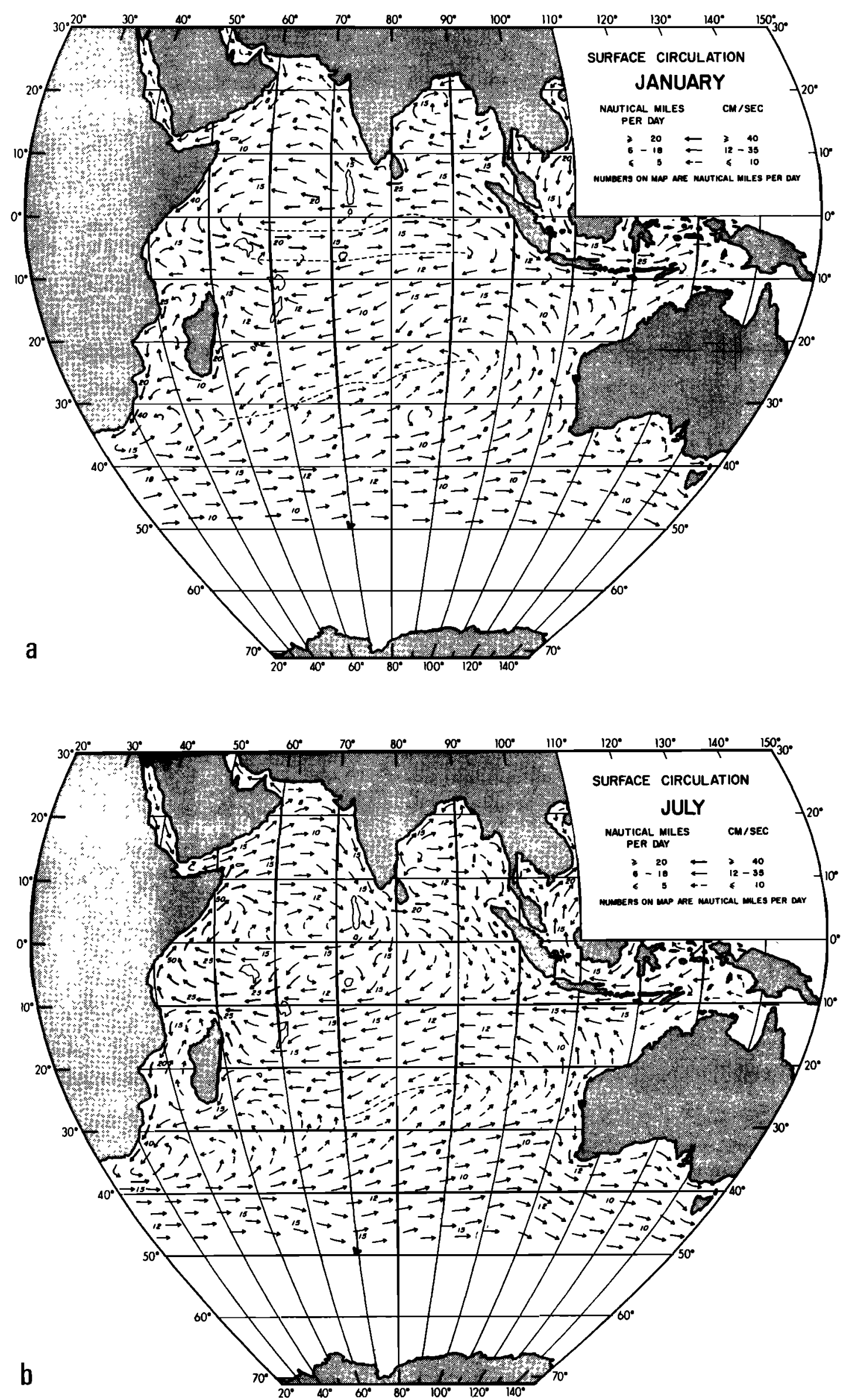

Fig. 1. Observed large scale surface circulation during (a) NE and (b) SW monsoons from an analysis of ship drift data (courtesy of K. Wyrtki). 
southward branches. During the northeast monsoon (November to March), the northward branch rounds the tip of Madagascar and continues north along the African coast as the East African Coastal Current (EACC) to meet the southward Somali Current. They turn offshore together at about $3^{\circ} \mathrm{S}$ [Schott, 1983; Schott et al., 1988] and form the eastward South Equatorial Countercurrent (SECC). During the southwest monsoon (May to September), the EACC feeds into the northward Somali Current and return flow is via the Southwest Monsoon Current from the northem hemisphere.

The model simulation reproduces this southem hemisphere tropical gyre defined by the westward SEC to the south, the eastward SECC to the north, and the EACC in the west. The western part of the gyre is a region of high eddy activity. The model flows split around the islands in the domain with transports that compare well with observations.

Available observational data from the equatorial and southern Indian Ocean are concentrated in a few regions. Wyrtki [1973] and Knox [1976] documented the zonal jets and current reversals at the equator during monsoon transitions. Luyten and Roemmich [1982] showed a semiannual period dominating the zonal currents near the African coast, with a dominant 26-day period in the meridional velocities at $200 \mathrm{~m}$. The latter were shown to be mixed Rossby-gravity, or Yanai, waves generated at the western boundary [Kindle and Thompson, 1989; Moore and $M c C r e a r y, 1989]$. South of the equator, several studies have found 40- to 50-day oscillations in the alongshore currents between $0^{\circ}$ and $5^{\circ} \mathrm{S}$ [Mertz and Mysak, 1984; Mysak and Mertz, 1984] and off the northern tip of Madagascar [Quadfasel and Swallow, 1986; Schott et al., 1988]. Schott et al. [1988] and Swallow et al. [1988] present transport calculations for the boundary currents along eastern Madagascar and question the existence of a seasonal cycle. Various methods have been used to estimate the throughflow from the Pacific into the Indian Ocean through the Indonesian islands [Godfrey and Golding, 1981; Piola and Gordon, 1984; Fine, 1985; Gordon, 1986]. In addition to these observations, we compare our model results with the transports and oscillations in another reduced gravity model [Schott et al., 1988; Kindle and Thompson, 1989].

In the following pages we first describe the model and the seasonal cycle of the winds used to force it. We then present the results of the model simulation and highlight agreement with observations, looking first at the large-scale circulation and then at the areas of interest noted above. We conclude with an overview of the wind-driven circulation and a discussion of the strengths and weaknesses of the present model.

\section{MODEL}

The model used is that described by Luther and $O^{\prime} B$ rien [1985], Luther et al. [1985], and Simmons et al. [1988]. For the model domain, realistic geometry of the Indian Ocean basin is used from $35^{\circ} \mathrm{E}$ to $120^{\circ} \mathrm{E}$ and from $25^{\circ} \mathrm{S}$ to $26^{\circ} \mathrm{N}$ as shown in Figure 2 . The boundary conditions at all solid (land) boundaries are the no-slip conditions: $u=v=0$. Most of the southern boundary along $25^{\circ} \mathrm{S}$ and a portion of the eastern boundary from $10^{\circ} \mathrm{S}$ to $20^{\circ} \mathrm{S}$ are open boundaries. The boundary condition applied there is the Sommerfeld radiation condition described by Camerlengo and O'Brien [1980]. The 200-m depth contour defines the model land boundaries. The shallow banks and islands in the domain

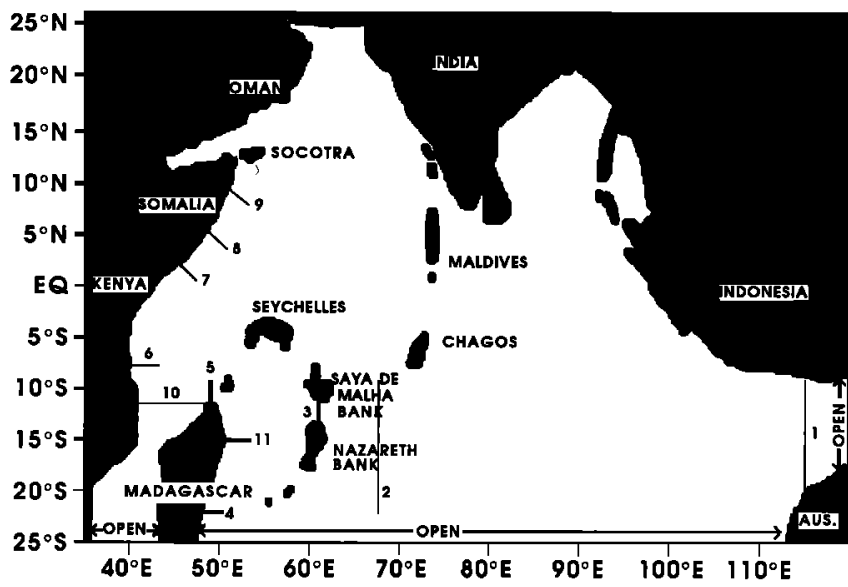

Fig. 2. Model geometry following the $200 \mathrm{~m}$ depth contour. Land boundaries are shaded. This study focuses on the region south of $5^{\circ} \mathrm{N}$. Islands in this region are identified in the text. Also indicated are the numbered sections used for the transport calculations shown in Figures 4-10 and 12-13.

include the Laccadive and Maldive islands, the Chagos Archipelago, and the banks around Socotra and along the Seychelles-Mauritius Ridge. These are all treated as land (closed) boundaries. Along the Seychelles-Mauritius Ridge, the major banks and island groups are the Seychelles $\left(5^{\circ} \mathrm{S}\right.$, $\left.55^{\circ} \mathrm{E}\right)$, Saya de Malha Bank $\left(10^{\circ} \mathrm{S}, 63^{\circ} \mathrm{E}\right)$, and Nazareth Bank $\left(15^{\circ} \mathrm{S}, 63^{\circ} \mathrm{E}\right)$. These banks are generally less than $30-40 \mathrm{~m}$ deep and are dotted with reefs and small islands. They present significant barriers to the upper level flow in the region and are therefore treated as closed boundaries.

The model is forced by the monthly mean climatological winds of Hellerman and Rosenstein [1983]. The Global Marine Sums wind speed climatology from the National Climate Data Center is used to compute and divide out an average drag coefficient from the Hellerman-Rosenstein stress data, recovering values of pseudostress, $W W$, where $W$ is the vector wind velocity and $W$ is its magnitude, as described in Legler et al. [1989]. This is done for reasons of consistency with other wind data products. The $2^{\circ}$ by $2^{\circ}$ gridded data set is interpolated to the model grid $\left(0.2^{\circ}\right.$ between like grid points) using a bicubic spline interpolating procedure. We assume that each monthly mean represents the value at the middle of the respective month and interpolate linearly between them to obtain a pseudostress data set covering a full annual cycle at the model time step of $20 \mathrm{~min}$. We convert the pseudostress fields back to wind stress using the bulk aerodynamic formula

$$
\tau=\rho_{a} C_{D} W W
$$

where $\rho_{a}$ is the density of air and $C_{D}$ is a constant drag coefficient. The drag coefficient thus becomes a parameter of the model rather than of the wind analysis. For the results presented here, $\rho_{a}=1.2 \mathrm{~kg} \mathrm{~m}^{-3}$ and $C_{D}=1.5 \times 10^{-3}$.

The model is integrated from rest starting at $000 \mathrm{UT}$ on December 16 with an initial value of model upper layer thickness (ULT) set at $H_{0}=200 \mathrm{~m}$. For the results presented here, we set the kinematic eddy viscosity $A$ equal to 750 $\mathrm{m}^{2} \mathrm{~s}^{-1}$ and the reduced gravity $g^{\prime}$ to $0.03 \mathrm{~m} \mathrm{~s}^{-2}$. For simplicity, the model year has 360 days, with 30 days in each month. The model is integrated for 20 years, with the annual wind cycle repeated year after year. After approximately 6 to 8 years of integration, the model has 
settled into a steady, repeating seasonal cycle, with only small differences from one year to the next occurring in regions with highly nonlinear flows [Luther and $O^{\prime} B r i e n$, 1989]. Results from the tenth year are presented here.

\section{WINDS}

Figure 3 shows the wind and curl fields over the model domain at the height of the northeast and southwest monsoons from the climatological winds of Hellerman and Rosenstein [1983] that are used to force the model. For a complete description of the atmospheric fields over this region, see the excellent atlas by Hastenrath and Lamb [1979]. The seasonal cycle of winds over the Indian Ocean is dominated by the monsoon reversals in the northem hemisphere. Differential heating drives oscillations in northern and southern hemisphere pressure systems causing seasonal changes in the winds. During the northern hemisphere winter, the northeast monsoon is characterized by a high pressure center that exists over central Asia, driving northeasterly winds across the northem Indian Ocean into a trough near the equator. (We use the meteorological convention of describing the wind by the direction from which it is blowing, while we use the oceanographic convention of naming the direction toward which a current is flowing; thus, a westward current flows in the same direction as an easterly wind.) During the southwest monsoon of northem hemisphere summer, a high-pressure center develops over Madagascar and the Mascarene Basin with concurrent intensification of the southeast tradewinds. The trades blow across the equator, are redirected toward the northeast by the African highlands, and form a strong atmospheric jet, often called the Findlater jet [Findlater, 1971], which blows into a trough situated over northem India.

The northeast (NE) monsoon lasts from November through March with strongest northeasterly (southwestward) winds in January along the Somali coast to about $15^{\circ} \mathrm{S}$ (Figures $3 a$ and $3 b$ ). The northeasterly winds are associated with negative curl along the coast and positive curl on the eastern side of the jet axis. Patterns of stress and curl remain similar in February through March, although the strength of both decreases as the NE monsoon decays. By April the winds north of Madagascar are southeasterly as the trades extend to the African coast.

The onset of the SW monsoon begins in May with southerly winds curving along the entire African coast. Curl patterns have changed sign north of $10^{\circ} \mathrm{S}$. These stress and curl patterns intensify dramatically during May through July (Figures $3 c$ and $3 d$ ). A sharp curl gradient over the Arabian Sea follows the axis of the southwesterly Findlater jet [Findlater, 1971]. The SW monsoon decays in August and September with the transition from $\mathrm{SW}$ to $\mathrm{NE}$ monsoon occurring in October. The NE monsoon intensifies through the end of the year with reversals in direction of the wind stress and the sign of the curl patterns along the African coast.

In the equatorial region, westerly winds predominate away from the coast with relatively strong westerly maxima present during monsoon transition months of April and October. During the height of the NE monsoon, equatorial winds have a northerly component changing to westerly south of the equator. Curl is positive in a $10-15^{\circ}$ band along the equator. In April wind stress curl is near zero all along the equator, becoming negative by May as winds strengthen and become more southerly. As in coastal regions, these patterns intensify through July and then decay through September. During the October transition from SW to NE monsoon, the changing winds in the Arabian Sea converge near the southern tip of India, forming a westerly maximum at $5^{\circ} \mathrm{N}, 80^{\circ}-85^{\circ} \mathrm{E}$, and near-zero wind stress curl is again found along the equator.

The trade winds in the southern hemisphere are southeasterly throughout the year. In January they are strongest in the southeast, turning easterly at about $60^{\circ} \mathrm{E}$, and converging over Madagascar with the NE monsoon winds crossing the equator (Figure $3 a$ ). Southerly winds at the coast of Australia diverge to contribute both to the SE trades and to westerly winds at the eastern boundary of the model. Near zero wind stress curl is found across the basin near $20^{\circ} \mathrm{S}$, with negative curl to the north and positive curl to the south (Figure 3b). The trades strengthen in April, reaching the African Coast, and in May they extend across the equator with the onset of the SW monsoon, where they feed the Findlater Jet.

\section{MOdel CIRCUlation FIELDS}

Plate 1 shows the model fields for February and August for the model domain from the tenth year of the integration. (Plate 1 is shown here in black and white. The color version can be found in the separate color section in this issue.) The upper layer thickness, which mimics dynamic topography, and the major currents in the model are in good qualitative agreement with the climatologies of dynamic height and $20^{\circ}$ isotherm depth of Wyrtki [1971], with the ship drift data of Cutler and Swallow [1984], and with the climatology of mixed layer depth of Rao et al. [1989]. The monsoon reversals in the Somali Current, the formation of the great whirl in the (boreal) summer Somali Current, and the formation of the eddy field off of the Arabian Peninsula are well represented in the model and are consistent with previous simulations from an earlier version of the model described by Luther and $O^{\prime} B r i e n$ [1985], Luther et al. [1985] and Simmons et al. [1988]. We concentrate here on the seasonal circulation in the southern tropical Indian Ocean from $20^{\circ} \mathrm{S}$ to $5^{\circ} \mathrm{N}$. The primary feature of the circulation in this region is a basin-wide tropical wind-driven gyre, defined by the South Equatorial Current to the south, the South Equatorial Countercurrent to the north, and the East African Coastal Current as its western boundary current. This tropical gyre is in many respects similar to a mid-latitude wind-driven gyre, responding to the basin-wide wind stress curl distribution, with a western boundary current recirculation region characterized by intense eddy formation. It differs from a mid-latitude gyre in its proximity to the equatorial wave guide and in the extreme seasonal wind variations with the changing monsoons. Because of the seasonal cycle in the winds, the northern limit of this gyre migrates between the northern and southern hemispheres, so that the western boundary current crosses the equator during the southwest monsoon and feeds the northwestward Somali Current. The presence of the equatorial wave guide allows energy to propagate away from the western boundary in the form of equatorial Kelvin waves and mixed Rossby-gravity waves. These waves are not available in a mid-latitude western boundary region. The low latitude of this gyre allows energy input by the winds across the interior to propagate westward much more rapidly. 

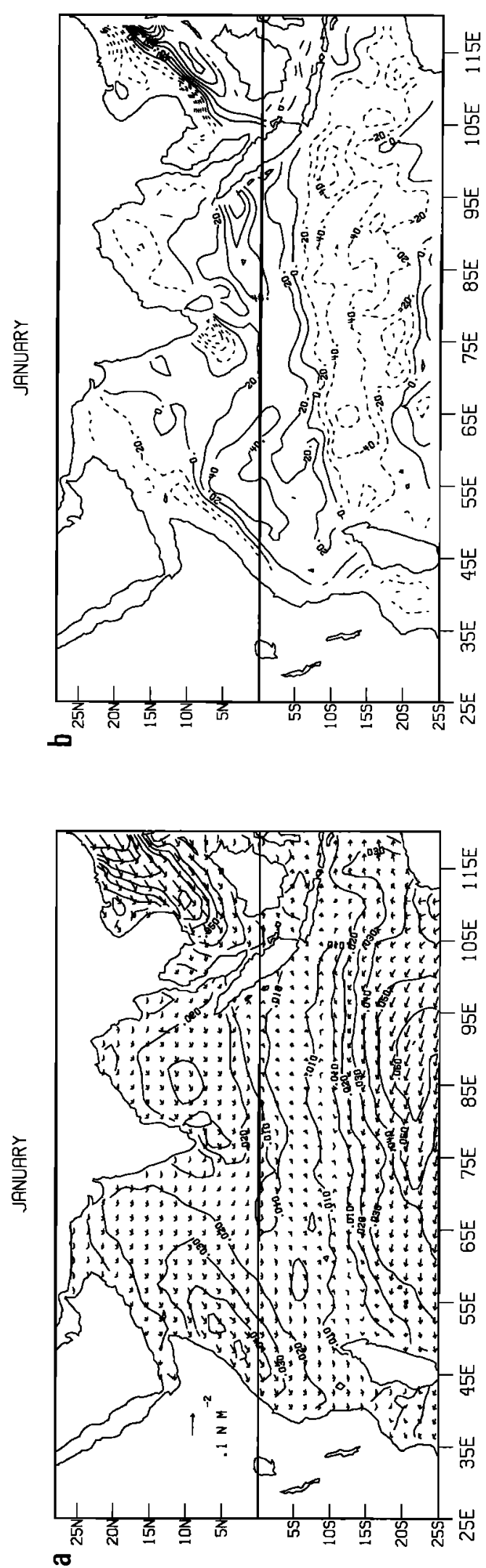

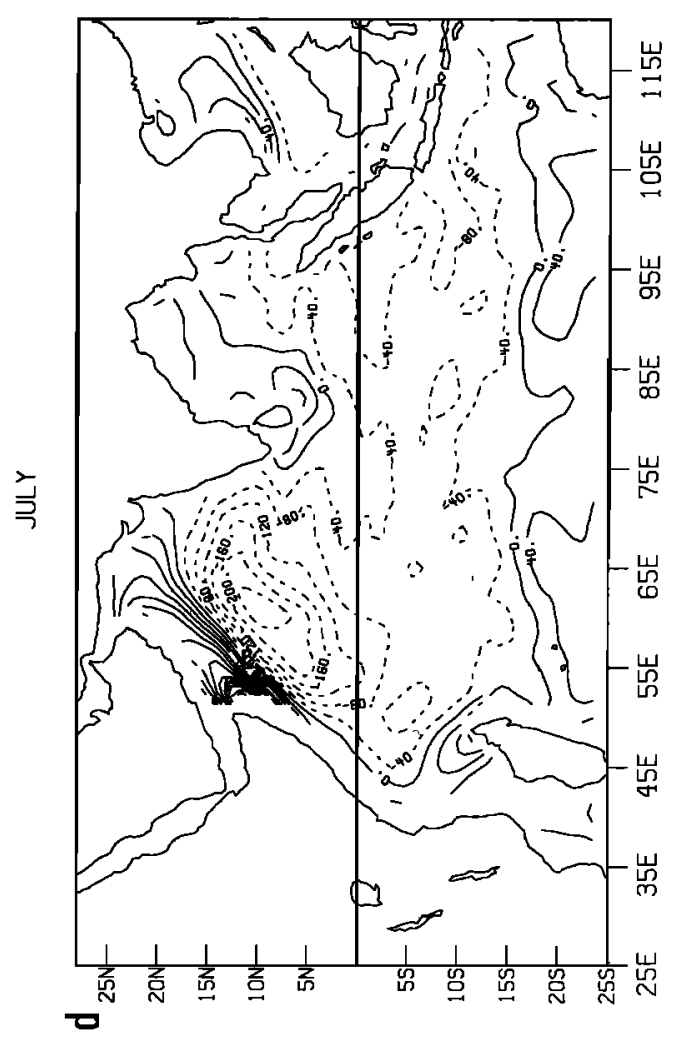

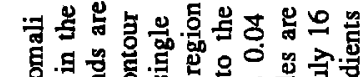

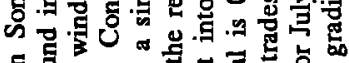

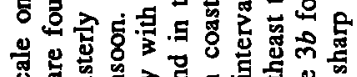
可

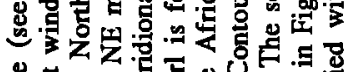

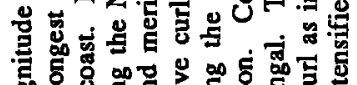

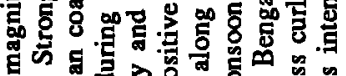

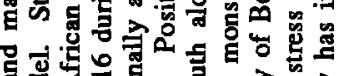

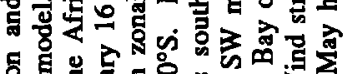

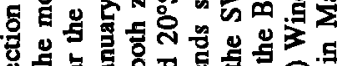

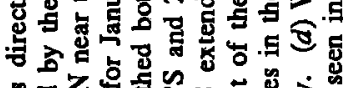

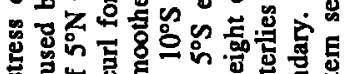
के

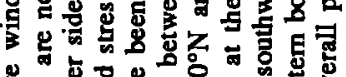

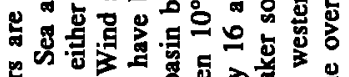

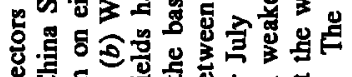
๖ं

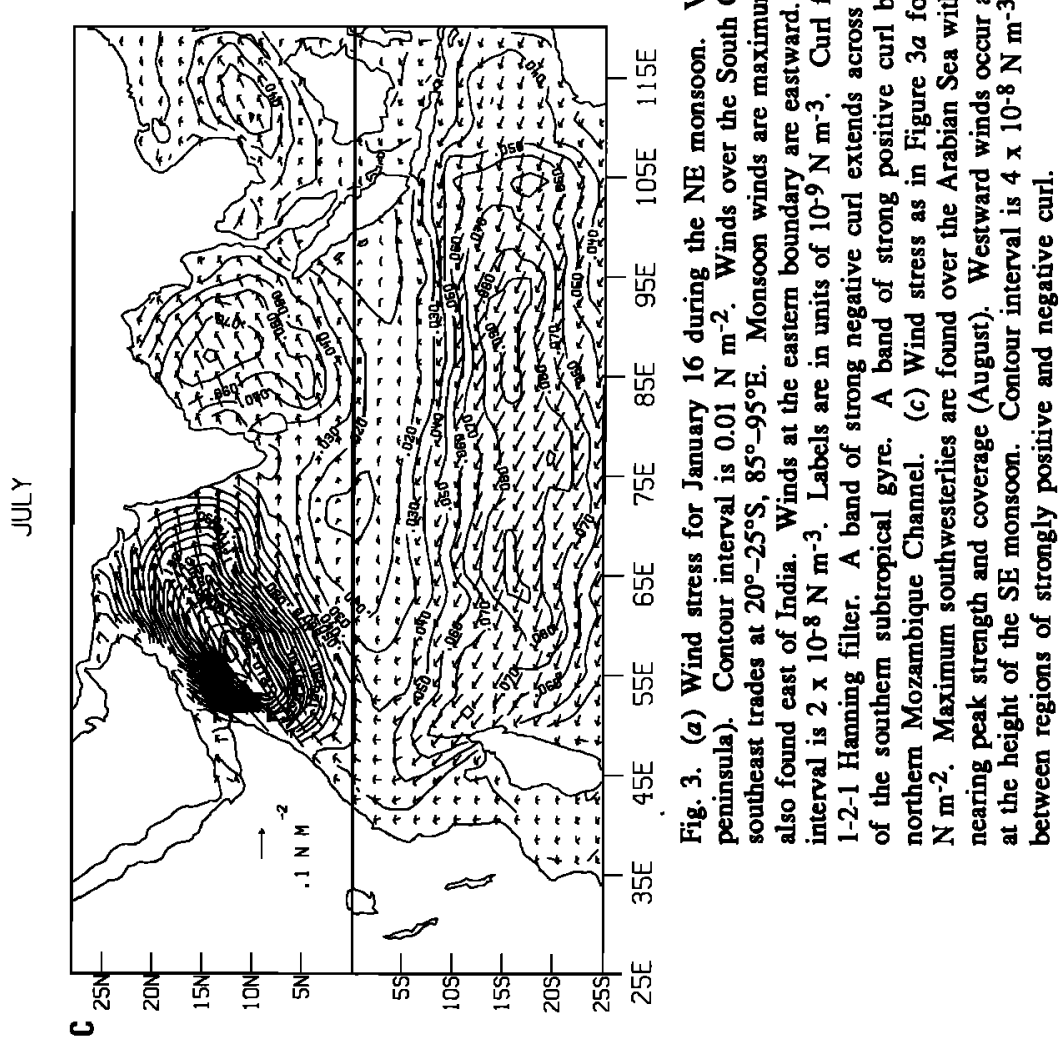




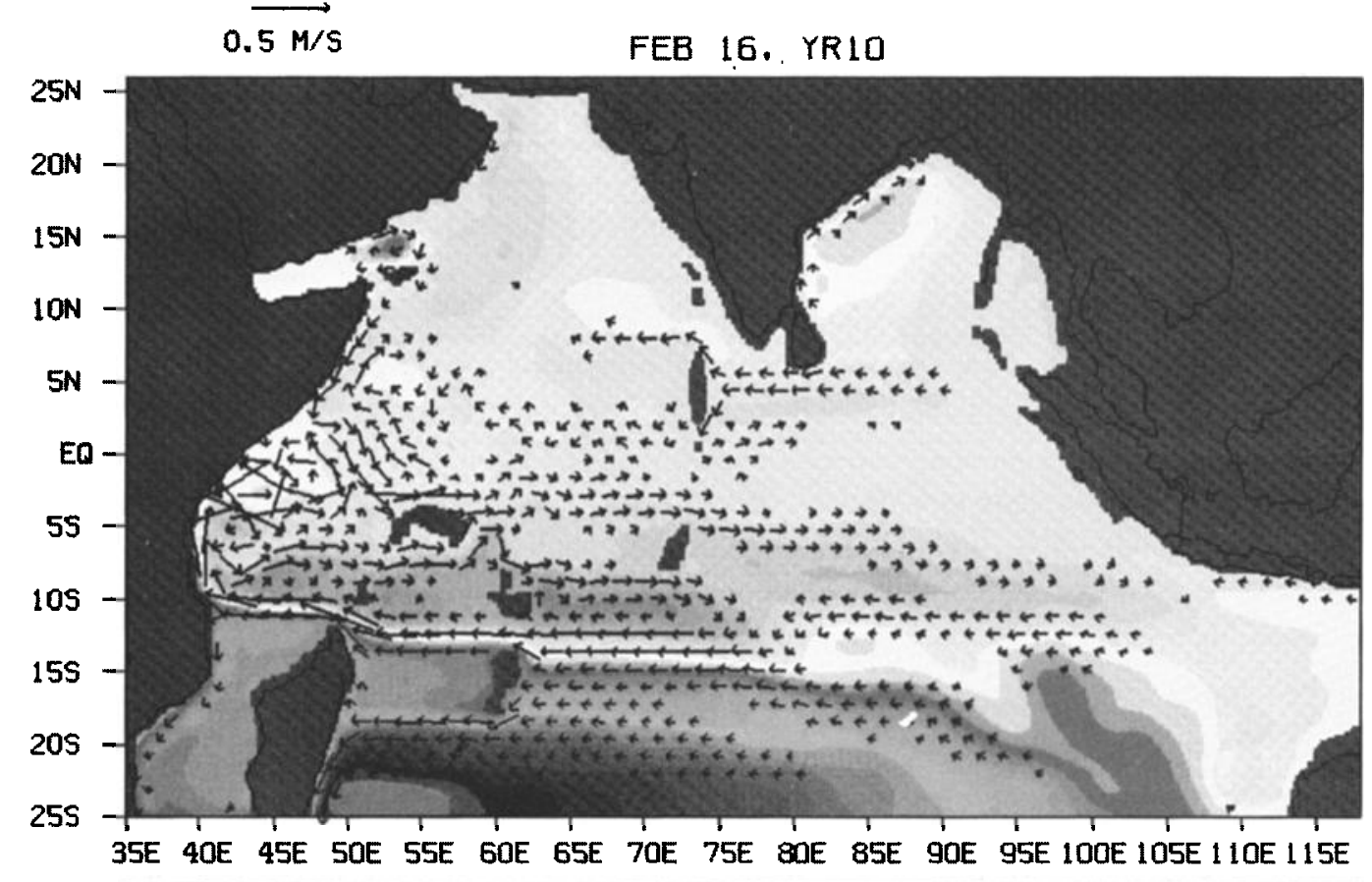

a

$\begin{array}{lllllllllllllll}140 & 152 & 164 & 176 & 188 & 200 & 212 & 224 & 236 & 248 & 260 & 272 & 284 & 296 & 308\end{array}$

\section{$0.5 \mathrm{M} / \mathrm{S}$}

AUG 16. YR10

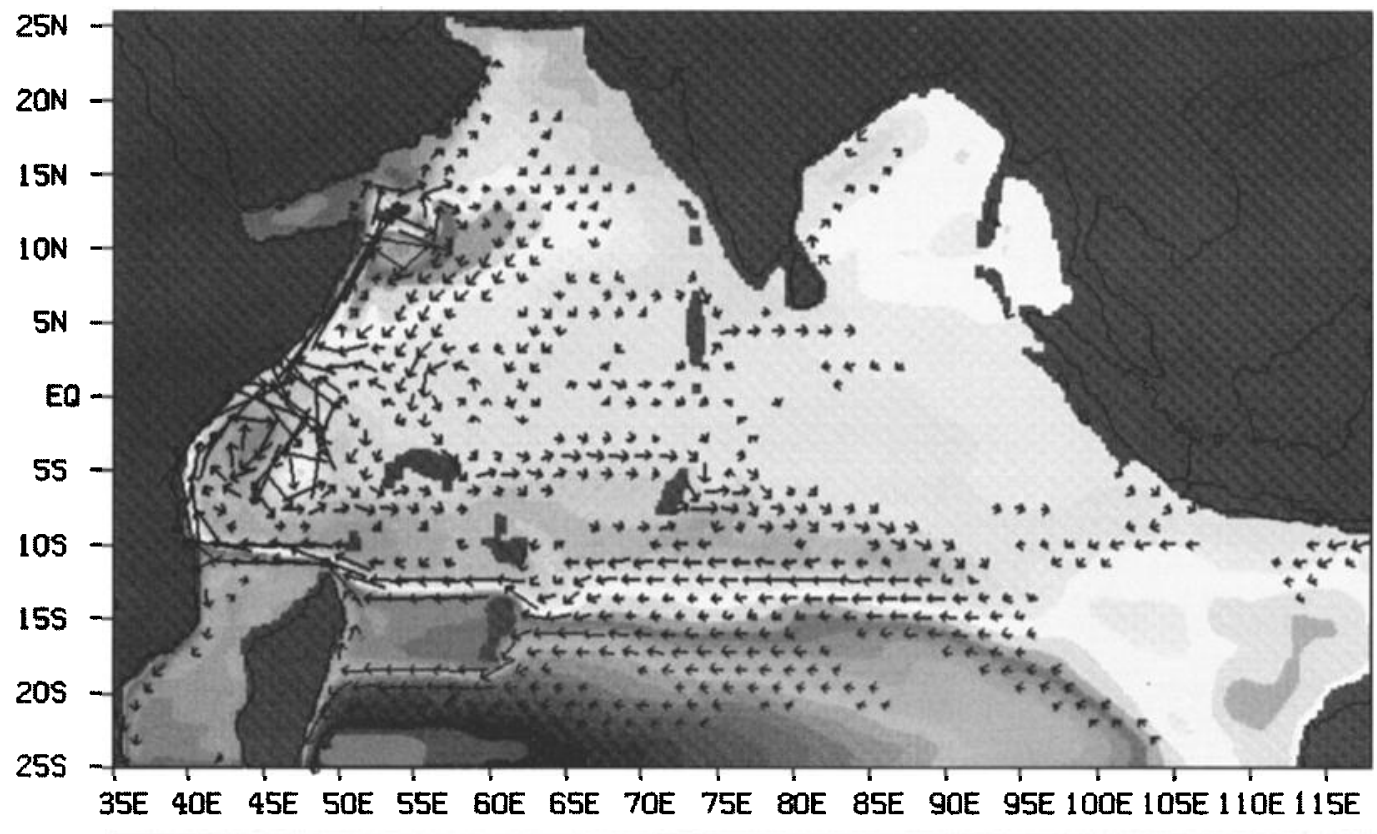

b

$$
\begin{array}{lllllllllllllll}
140 & 152 & 164 & 176 & 188 & 200 & 212 & 224 & 236 & 248 & 260 & 272 & 284 & 296 & 308
\end{array}
$$

Plate 1. Model upper layer thickness and velocity from the tenth year of integration. Arrows indicate upper layer velocity, with only one arrow shown each $1.6^{\circ}$ in latitude and longitude. Arrows representing velocities greater than $1.0 \mathrm{~m} \mathrm{~s}^{-1}$ are truncated, and those less than $0.05 \mathrm{~m} \mathrm{~s}^{-1}$ are supressed for clarity of display. Scale arrow is shown at upper left. (a) February. (b) August. (The color version and a complete description of this figure can be found in the separate color section in this issue.)

In this section, we describe this tropical gyre beginning with the westward flow in the SEC, then the western boundary region and finally the equatorial currents and the SECC. The model fields are compared with observational evidence wherever possible. Because we are discussing flows in both northern and southern hemispheres, we will refer to the sense of rotation of a flow as either clockwise (cyclonic in the southern hemisphere, anticyclonic in the northern) or 
counterclockwise (anticyclonic in the southern hemisphere, cyclonic in the Northern).

\subsection{The South Equatorial Current}

The SEC is observed as a broad westward flow between $8^{\circ} \mathrm{S}$ and about $20^{\circ} \mathrm{S}$, with transports between 33 and $39 \mathrm{~Sv}$ [Wyrtki, 1971; Godfrey and Golding, 1981; Pickard and Emery, 1982]. The model reproduces this flow as a meandering westward current between $10^{\circ}$ and $20^{\circ} \mathrm{S}$, with maximum transport between $12^{\circ}$ and $15^{\circ} \mathrm{S}$ (Plate 2). (Plate 2 is shown here in black and white. The color version can be found in the separate color section in this issue.) East of the Seychelles-Mauritius Ridge (SMR), the annual mean westward transport in the model SEC at $63^{\circ} \mathrm{E}$ between $8^{\circ} \mathrm{S}$ and $23^{\circ} \mathrm{S}$ is $24.3 \mathrm{~Sv}$, ranging between 23 and $25.5 \mathrm{~Sv}$ (Figure 4). The SEC separates the clockwise tropical gyre, which is driven by the cyclonic (negative) wind stress curl distribution to the north, from a counterclockwise subtropical gyre to the south, which is driven by the anticyclonic (positive) wind stress curl distribution there. This subtropical gyre straddles the southern open boundary of the model, so that only its northem half is represented. The SEC roughly follows the line of zero wind stress curl.

The atlas of Wyrtki [1971] shows seasonal variability in the latitudinal range of the SEC, as pointed out by Schott [1983]. In boreal summer, the SEC is shown between about $12^{\circ}$ and $22^{\circ} \mathrm{S}$, while in winter it is shown as narrower and located a few degrees farther to the south, between approximately $15^{\circ}$ and $20^{\circ} \mathrm{S}$. Similar seasonal variability is also seen in the climatology of mixed layer depth of Rao et al. [1989]. Inspection of Plates 1 and 2 shows similar variability in the model to the east of $60^{\circ} \mathrm{E}$. This variability is generated to the east of $100^{\circ} \mathrm{E}$ by the annual cycle in the wind stress curl and propagates westward as a Rossby wave at approximately $0.1 \mathrm{~m} \mathrm{~s}^{-1}$. Plate 3 shows a time-longitude section of model ULT through the SEC along $12^{\circ} \mathrm{S}$. The westward propagation of these features can be seen from their origin to the east of $100^{\circ} \mathrm{E}$. Similar westward propagating features are seen in sea surface topography from GEOSAT altimetry data (C. Perigaud, personal communication, 1989), and in model simulations by Perigaud and Delecluse [1989] and by Kindle and Thompson [1989]. This Rossby wave energy is partially blocked by the banks along the Seychelles-Mauritius Ridge at $60^{\circ} \mathrm{E}$. In March through June, a small clockwise eddy forms to the east of the SMR between $10^{\circ}$ and $12^{\circ} \mathrm{S}$, most likely due to nonlinear interactions among the incoming long Rossby waves and the reflected short Rossby waves [see Pedlosky, 1987]. By late July, this eddy has become small enough in diameter that it is advected through the gap in the SMR at $12^{\circ}$ to $13.5^{\circ} \mathrm{S}$ and continues toward the west. This advective oscillation appears to be the source of the 70-day oscillations seen in the model transport at the east coast of Madagascar.

The SEC is diverted by the southern portion of the SMR between $13.5^{\circ}$ and $17^{\circ} \mathrm{S}$ (the Nazareth Bank and the Cargados Carajos Shoals). In the mean, $10.9 \mathrm{~Sv}$ of the flow passes through the gap between $12^{\circ}$ and $13.5^{\circ} \mathrm{S}$ (Figure 5) and on to the coast of Madagascar, while a substantial portion flows to the south around the SMR and then toward the west between $17^{\circ}$ and $19^{\circ} \mathrm{S}$. This southern branch of the SEC splits again at the east coast of Madagascar into the southward flowing East Madagascar Current (EMC), which flows out of the model domain through the southem open boundary, and a previously unnamed northward current which we call the Northeast Madagascar Current (NMC). The latitude of this splitting is consistent with the observed split at $17^{\circ} \mathrm{S}$ from Schott et al. [1988]. Transports in the EMC range from 9 to $12 \mathrm{~Sv}$, with a mean of 10.3 (Figure 6). The NMC, with a mean transport of $0.6 \mathrm{~Sv}$ (Figure 7), combines with the northem branch of the SEC at $13^{\circ} \mathrm{S}$. The combined current flows around Cape Amber at the northern tip of Madagascar, with mean transport of $16.9 \mathrm{~Sv}$ (Figure 8), and then continues westward to the African coast, where it feeds the EACC. A portion of this current $(0.5 \mathrm{~Sv}$ in the mean; Figure 9) flows to the south through the Mozambique Channel along the African coast and out the southem boundary, as in the atlas of Wyrtki [1971] and in the observations of Lutjeharms et al. [1981]. Weak counterclockwise eddies form in the northern part of the channel, similar to those described by Saetre and da Silva [1984].

Schott et al. [1988] present transport calculations from current meter moorings at $12^{\circ} \mathrm{S}$ and at $23^{\circ} \mathrm{S}$. Swallow et al. [1988] estimated mean geostrophic transports from hydrographic sections in the same regions. The moorings at Cape Amber were located between $11^{\circ} \mathrm{S}$ and $12^{\circ} \mathrm{S}$. Transports were calculated parallel to the main current axis of $313^{\circ} \mathrm{T}$. Schott et al. [1988] calculated a value of $10.8 \mathrm{~Sv}$ for the top $200 \mathrm{~m}$, noting that their horizontal length scales do not include all of the current through the region. The model transport in the upper $200 \mathrm{~m}$ at $49^{\circ} \mathrm{E}$ between $10^{\circ} \mathrm{S}$ and $12^{\circ} \mathrm{S}$ has a mean value of $16.9 \mathrm{~Sv}$. There is some recirculation included in this transect that occurs to the north of $10^{\circ} \mathrm{S}$ which is due to clockwise circulation in the lee of the Farquhar group of islands and shoals at $10^{\circ} \mathrm{S}, 51^{\circ} \mathrm{E}$, to the north and east of Cape Amber. Model transport shows a seasonal variation of 3 to $4 \mathrm{~Sv}$ (Figure 8). The transport time series from the moorings shows no measurable seasonal signal between $150 \mathrm{~m}$ and $1100 \mathrm{~m}$ depth. Schott et al. [1988] note a negligible seasonal cycle in this current in the model of Kindle and Thompson [1989]. Swallow et al. [1988] conclude on the basis of shallow hydrography and historical ship drifts north of Madagascar that there may indeed be a seasonal variation of $\pm 2 \mathrm{~Sv}$ with a maximum in August-September and a minimum in January-February. The signal that they see appears to be trapped in the surface layer above the moored array analyzed by Schott et al. The model transect at Cape Amber shows a seasonal cycle with maximum transport of $19 \mathrm{~Sv}$ in July-September and minimum transport of $14.8 \mathrm{~Sv}$ in November-February.

The current axis for the second array of current meters was $25^{\circ} \mathrm{T}$ at $23^{\circ} \mathrm{S}$ across the EMC. The model transect at $22^{\circ} \mathrm{S}$ has a mean transport of $10.3 \mathrm{~Sv}$ (Figure 6). Schott et al. [1988] and Swallow et al. [1988] find transport values through this section of $7.0 \mathrm{~Sv}$ and $7.4 \mathrm{~Sv}$, respectively. The seasonal cycle from the model bears no resemblance to the seasonal cycle which Schott et al. [1988] describe for 0- to 1100 - $m$ transport for this section. This current passes through the southern open boundary of the model and forms part of the westem boundary current for the subtropical gyre to the south of $15^{\circ} \mathrm{S}$. Since this gyre is not resolved completely by the model, it is not surprising that the model fails to faithfully reproduce the EMC.

The reduced-gravity model of Kindle and Thompson [1989] ( see also Schott et al. [1988]) is also forced by the Hellerman-Rosenstein wind climatology and produces flows 
a
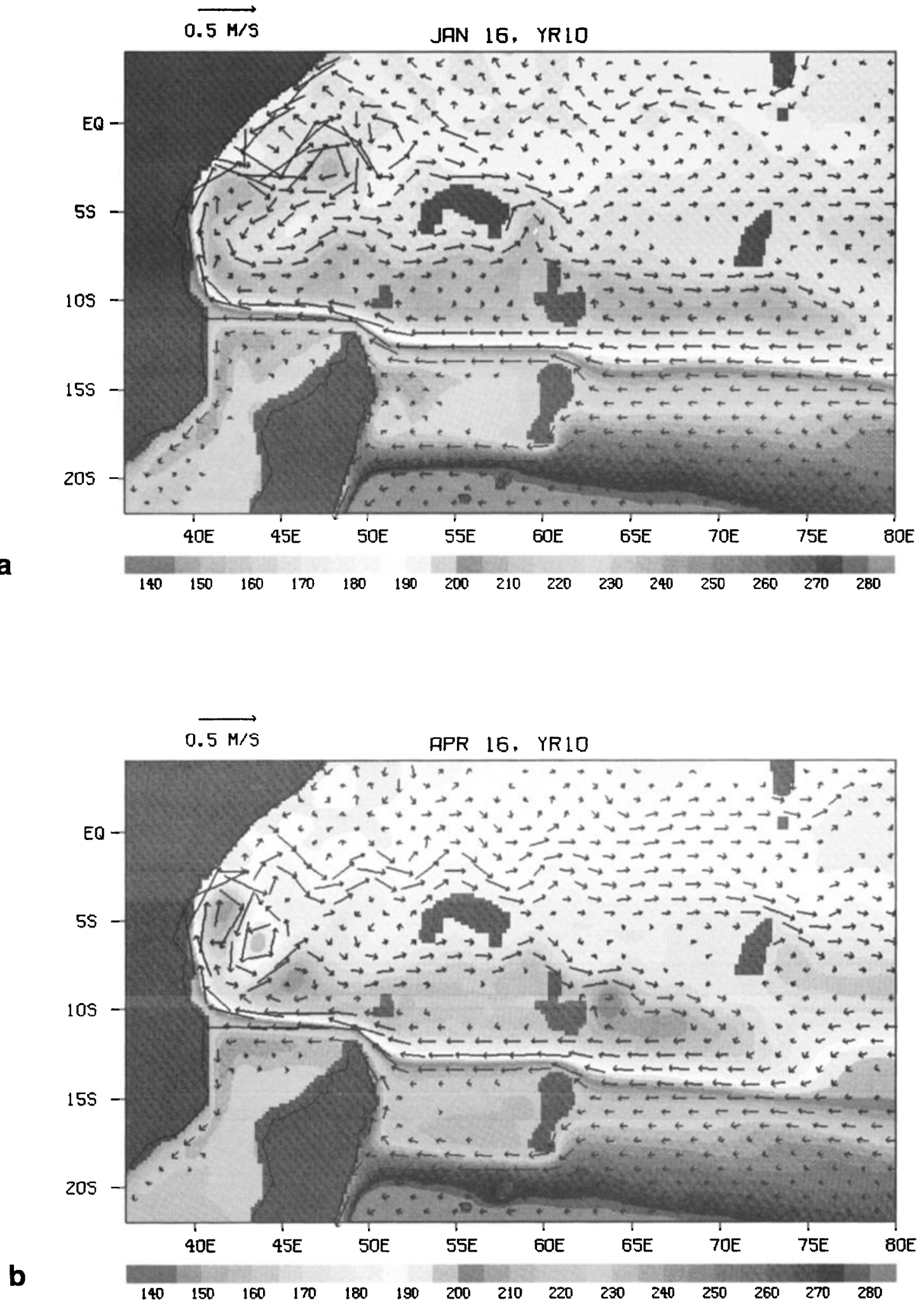

Plate 2. Southwestern area of the model domain $\left(36^{\circ} \mathrm{E}\right.$ to $80^{\circ} \mathrm{E}, 22^{\circ} \mathrm{S}$ to $\left.4^{\circ} \mathrm{N}\right)$. Arrows are as in Plate 1 . (a) January. (b) April. (c) July. (d) October. The Rossby wave between $8^{\circ}$ and $12^{\circ} \mathrm{S}$ is blocked by the Seychelles-Mauritius Ridge in January through April. An eddy forms to the east of the SMR and is advected through the gap at $11^{\circ}$ to $13^{\circ} \mathrm{S}$ in early July. Intense eddy activity is seen in the western boundary current recirculation region to the north of Madagascar and to the west of the Seychelles throughout the year. Mixed Rossby-gravity (or Yanai) waves are particularly evident in the equatorial region during the monsoon transition months of April and October. (The color version and a complete description of this figure can be found in the separate color section in this issue.) 

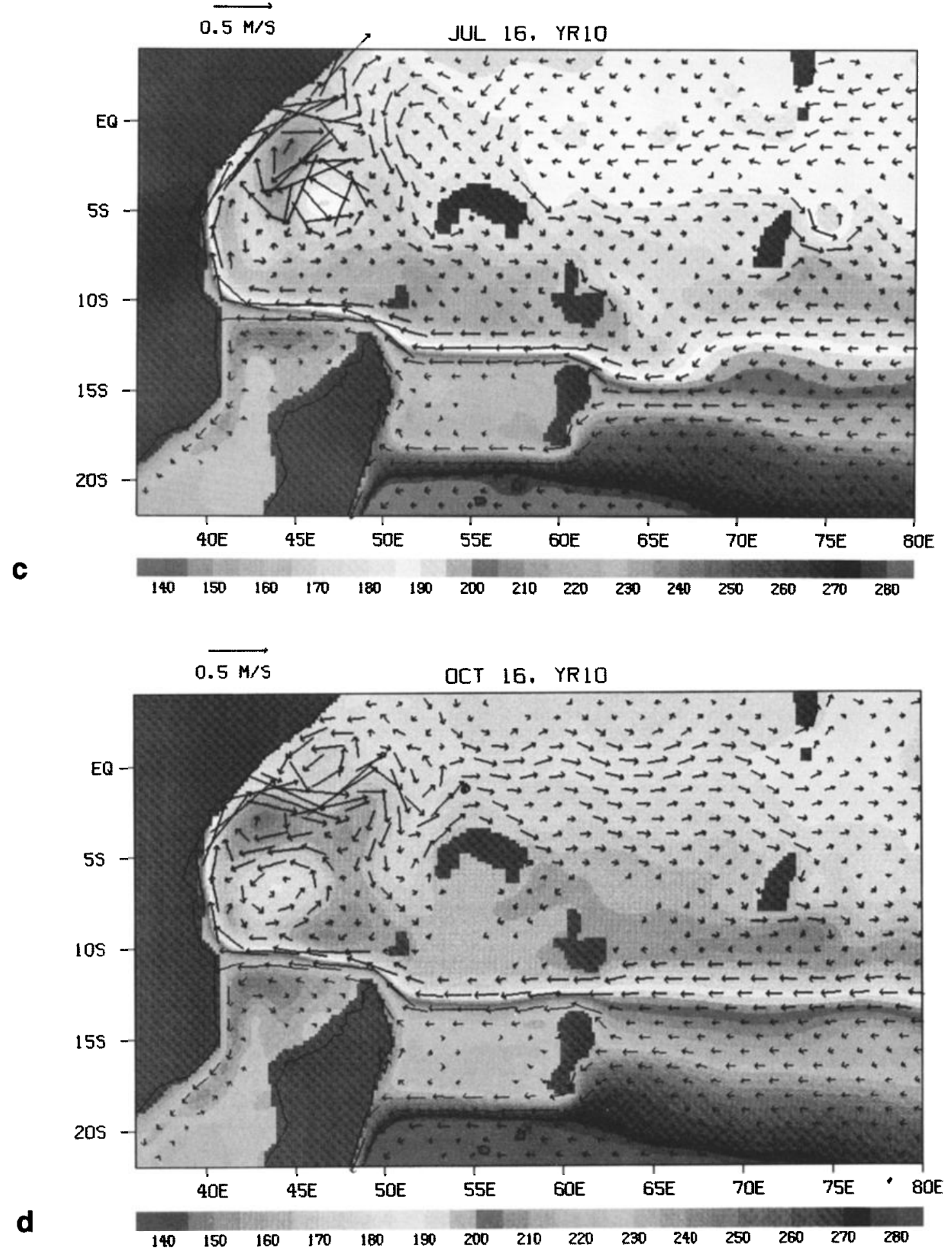

Plate 2. (continued)

which are very similar to those described here. Transport values from that model compare well with those calculated over the entire depth $(0-1100 \mathrm{~m})$ of the current meter array but are larger than those in the present model calculation. Kindle and Thompson [1989] use the full HellermanRosenstein stresses to drive their model, projected onto an upper layer that has a mean value of $275 \mathrm{~m}$. The conversion of the Hellerman-Rosenstein stresses to pseudostress, the use of a drag coefficient of $1.5 \times 10^{-3}$, and the projection of the wind stress onto a layer with mean thickness of only $200 \mathrm{~m}$ in the present model calculation (as described in section 2) account for the difference in model transports.

\subsection{East African Coastal Current}

Most of the flow from the SEC reaching the coast of Africa turns northward as a strong western boundary current, 
Fig. 4

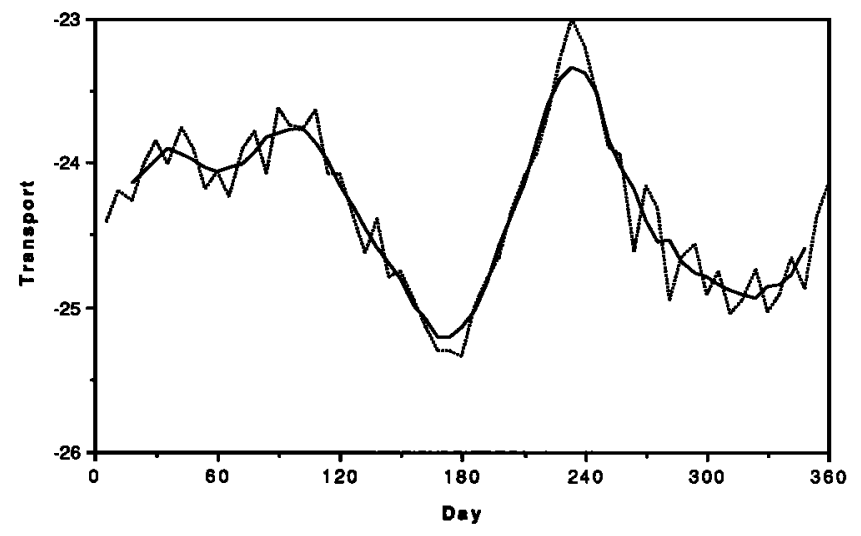

Fig. 4. Zonal transport in the SEC across $63^{\circ} \mathrm{E}$ between $8^{\circ} \mathrm{S}$ and $23^{\circ} \mathrm{S}$ (section 2). Time is in days after December 16, year 9. Transport is in sverdrups $\left(1 \mathrm{~Sv}=10^{6} \mathrm{~m}^{3} \mathrm{~s}^{-1}\right)$. Mean transport is 24.3 Sv to the west. Dashed line is instantaneous transport computed at 6-day intervals Solid line has been smoothed with a five-point (1 month) filter.

the East African Coastal Current (Plates 1 and 2). The mean transport in the model EACC at $8.2^{\circ} \mathrm{S}, 40^{\circ}$ to $43^{\circ} \mathrm{E}$, is 12.8 $\mathrm{Sv}$ to the north, with a range of $8.4 \mathrm{~Sv}$ in February to 17.7 $\mathrm{Sv}$ in May (Figure 10). The EACC is a tropical analog to a mid-latitude western boundary current, driven by the wind stress curl field over the interior of the basin. During the NE monsoon this current flows in conflict with the monsoon winds. Plate $2 a$ shows the EACC being met by the southward flowing Somali Current early in the year and turning offshore at $2^{\circ}-3^{\circ} \mathrm{S}$ in agreement with observations
[Düing and Schott, 1978; Schott, 1983]. The convergence between the EACC and the southward Somali Current moves to about $4^{\circ} \mathrm{S}$ in February-March with a clockwise eddy to the south and a counterclockwise (anticyclonic) eddy to the north. Although the northeasterlies are relaxing, this strong counterclockwise circulation remains through most of March before weakening and slowly giving way to northward flow at the coast. By late March, the weakening of the southward winter Somali Current has allowed the EACC to push northward, apparently through the inertial mechanism proposed by Anderson and Moore [1979]. The winds along the coast become southerly by mid-April and then enhance the northward inertial flow of the EACC as in the observations of Leetmaa [1972]. Strong northward flow is found along the African coast south of the equator by June and persists through July and August.

The model solutions (Plates 2a-2d) show strong recirculation and eddy formation south of the equator in the region of the EACC. Comparison of the mean transport in the EACC at $8.2^{\circ} \mathrm{S}(12.8 \mathrm{~Sv})$, into the Mozambique Channel (0.5 Sv) and that in the zonal current at Cape Amber (16.9 Sv) suggests that $3.6 \mathrm{~Sv}$ is recirculated in the EACC south of that latitude, while comparison of the transport past Cape Amber with that farther to the east and south suggests a recirculation of $5.4 \mathrm{~Sv}$ from the north. Maximum eddy kinetic energy (EKE) for the year is found near $3^{\circ} \mathrm{S}, 45^{\circ} \mathrm{E}$ (Figure 11). High EKE is found in the EACC south to about $9^{\circ} \mathrm{S}$. The strong shears in the region result in eddies being formed through barotropic instability. These ringlike eddies circulate in a clockwise fashion in this approximately $10^{\circ}$ by $10^{\circ}$ region, often merging and reinforcing each other. Counterclockwise eddies are generated just west of the Seychelles near $5^{\circ} \mathrm{S}$. They propagate westward to the African

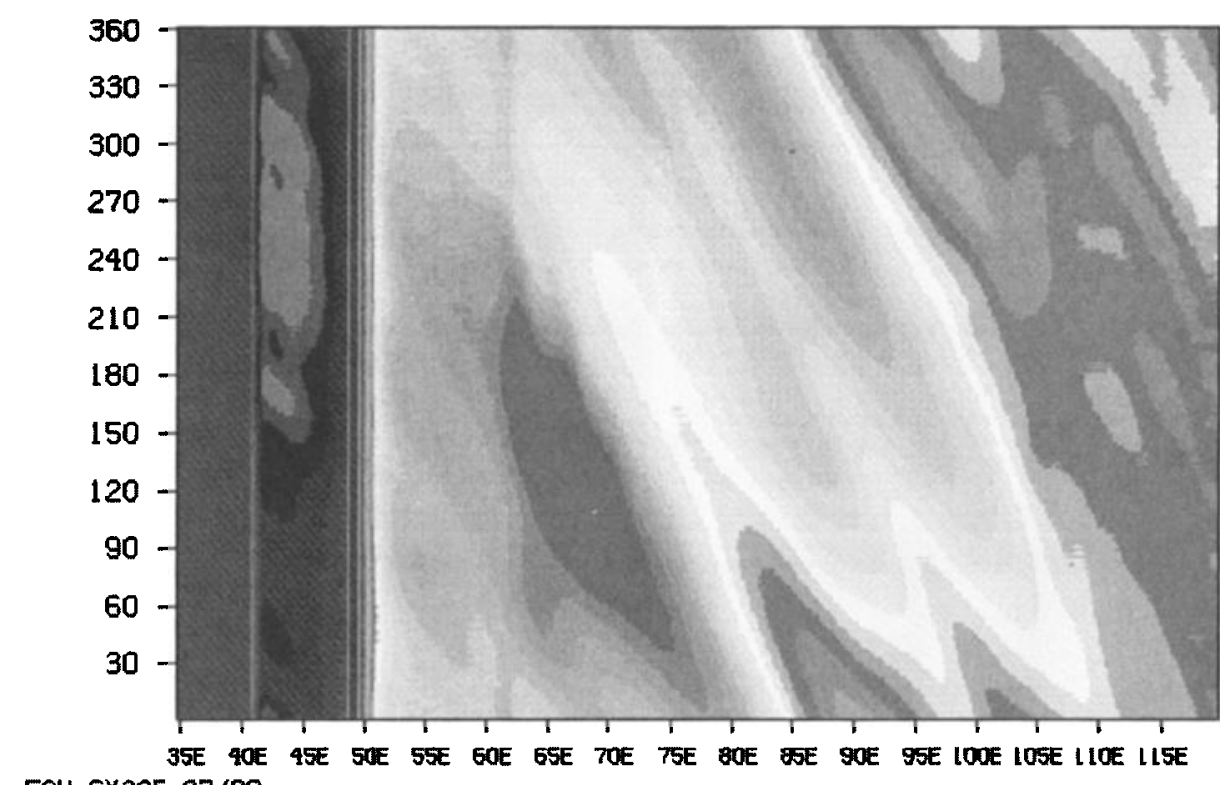

FSU CY205 07/89

(METERS)

$\begin{array}{lllllllllllllll}158 & 164 & 170 & 176 & 182 & 188 & 194 & 200 & 206 & 212 & 218 & 224 & 230 & 236 & 242\end{array}$

Plate 3. Time versus longitude contours of model upper layer thickness (ULT) along $12^{\circ} \mathrm{S}$. Time is in days after December 16 , year 9 . The Rossby wave generated east of $100^{\circ} \mathrm{E}$ is blocked by the Seychelles-Mauritius Ridge at $60^{\circ} \mathrm{E}$. An eddy shed through the gap in the ridge is seen to propagate westward until it is absorbed into the northward current at the east coast of Madagascar at $49^{\circ} \mathrm{E}$ (the brown vertical strip). (The color version and a complete description of this figure can be found in the separate color section in this issue.) 
Fig. 5

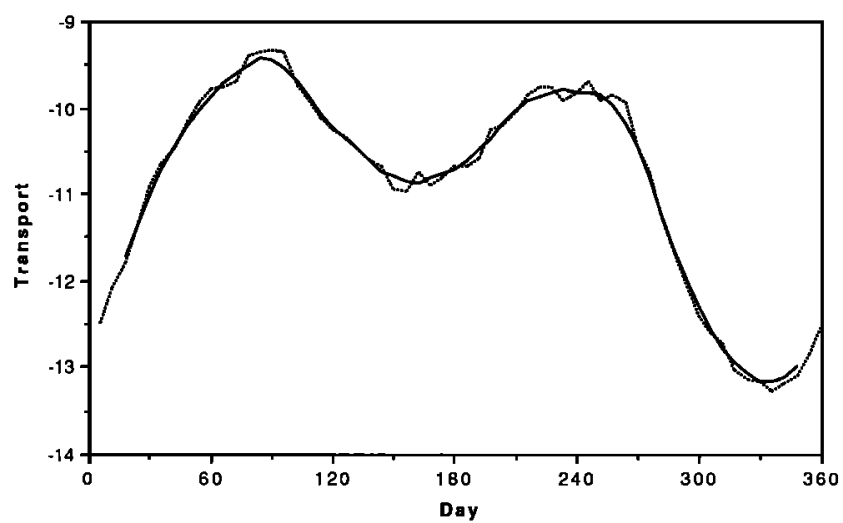

Fig. 5. Zonal transport in the SEC across $61^{\circ} \mathrm{E}$ between $13.4^{\circ} \mathrm{S}$ and $11.4^{\circ} \mathrm{S}$, through the gap between the Nazareth and Saya de Malha Banks along the Seychelles-Mauritius Ridge (section 3) as in Figure 4. Mean transport is $10.9 \mathrm{~Sv}$ to the west. Dashed line is instantaneous transport computed at 6-day intervals Solid line has been smoothed with a five-point (1 month) filter.

Fig. 6

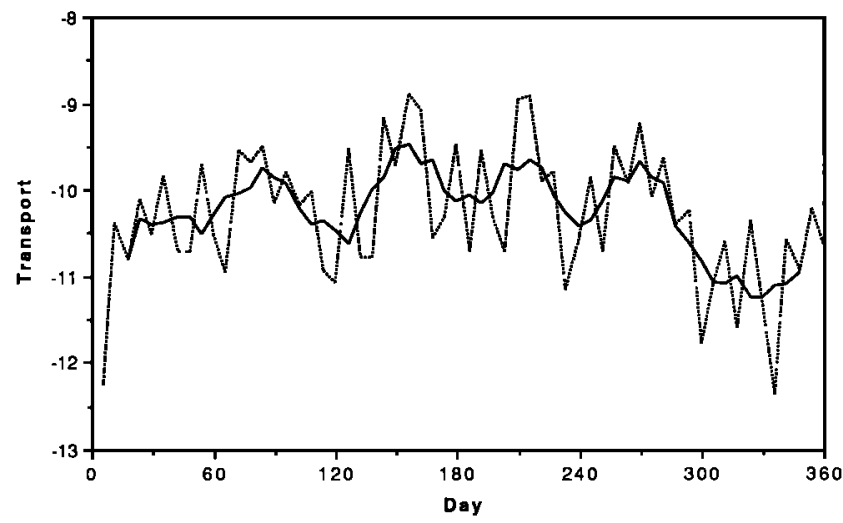

Fig. 6. Transport in the EMC across $22^{\circ} \mathrm{S}$ between $48^{\circ}$ and $50^{\circ} \mathrm{E}$ (section 4) as in Figure 4. Mean transport is $10.3 \mathrm{~Sv}$ to the south. Dashed line is instantaneous transport computed at 6-day intervals Solid line has been smoothed with a five-point (1 month) filter.

Fig. 7

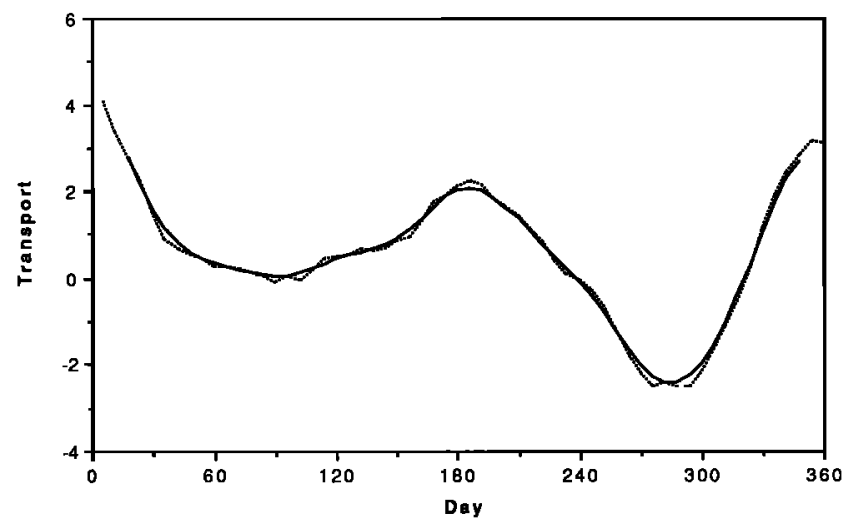

Fig. 7. Transport across $15^{\circ} \mathrm{S}$ between $50^{\circ}$ and $53^{\circ} \mathrm{E}$ (section 11) as in Figure 4. Mean transport is $0.6 \mathrm{~Sv}$ to the north. Dashed line is instantaneous transport computed at 6-day intervals Solid line has been smoothed with a five-point (1 month) filter.
Fig. 8

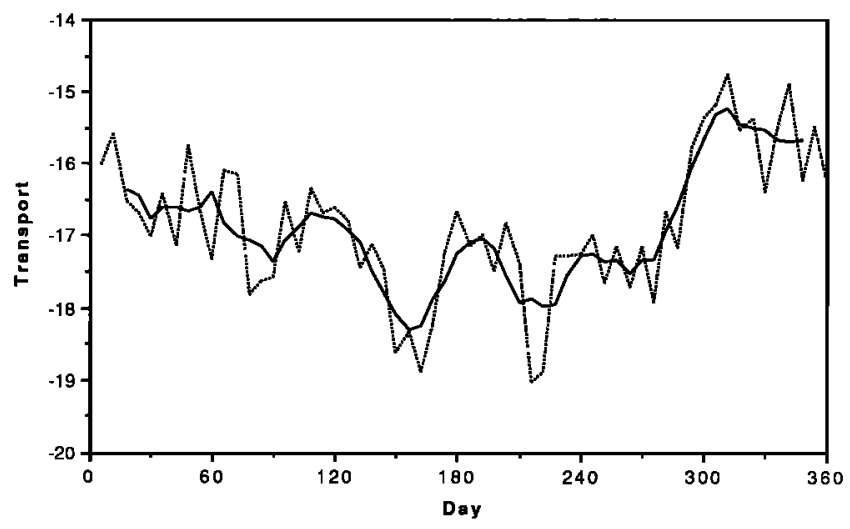

Fig. 8. Transport past Cape Amber across $49^{\circ} \mathrm{E}$ between $10^{\circ}$ and $12^{\circ} \mathrm{S}$ (section 5) as in Figure 4. Mean transport is $16.9 \mathrm{~Sv}$ to the west. Dashed line is instantaneous transport computed at 6-day intervals Solid line has been smoothed with a five-point (1 month) filter.

Fig. 9

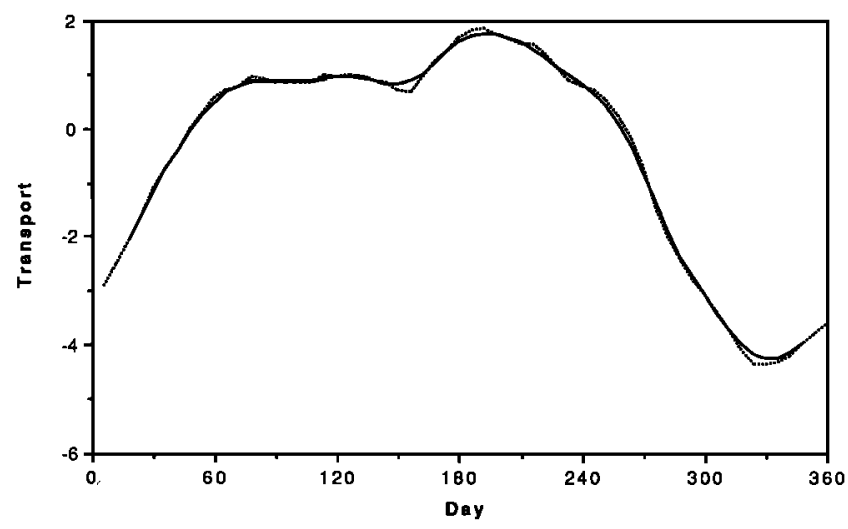

Fig. 9. Transport in the Mozambique Channel across $12^{\circ} \mathrm{S}$ between $41^{\circ}$ and $48^{\circ} \mathrm{E}$ (section 10) as in Figure 4. Mean transport is $0.5 \mathrm{~Sv}$ to the south. Dashed line is instantaneous transport computed at 6day intervals Solid line has been smoothed with a five-point (1 month) filter.

Fig. 10

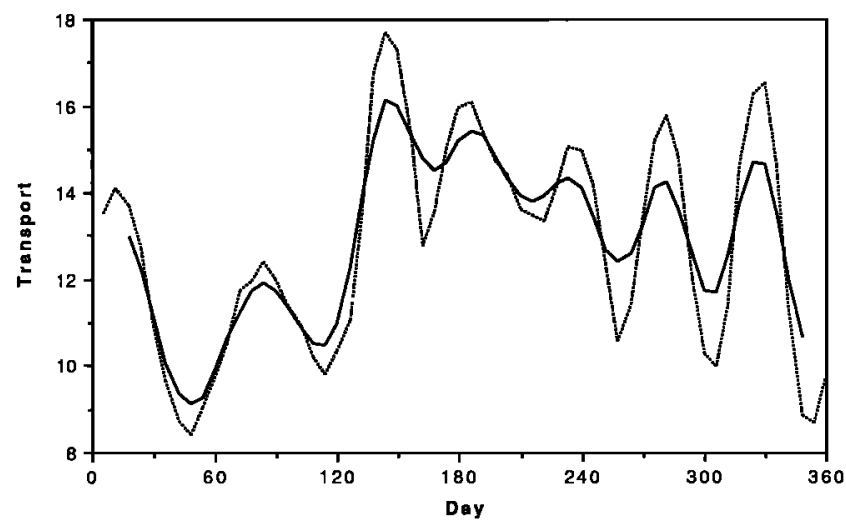

Fig. 10. Transport in the EACC across $8.2^{\circ} \mathrm{S}$ between $40^{\circ}$ and $43^{\circ} \mathrm{E}$ (section 6) as in Figure 4. Mean transport is $12.8 \mathrm{~Sv}$ to the north. Dashed line is instantaneous transport computed at 6-day intervals Solid line has been smoothed with a five-point ( 1 month) filter. 


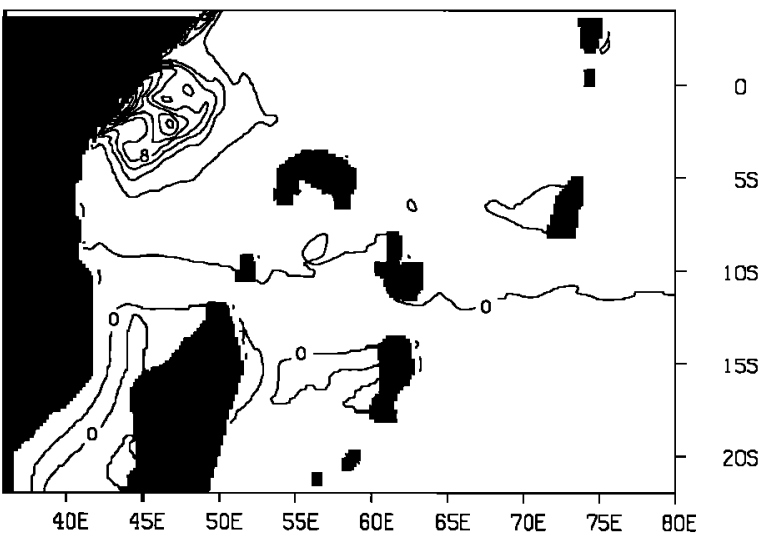

Fig. 11. Mean annual eddy kinetic energy (EKE) in the equatorial region near the African coast, $40^{\circ}-80^{\circ} \mathrm{E}, 5^{\circ} \mathrm{N}-12^{\circ} \mathrm{S}$. EKE is concentrated at the coast south of the equator with a maximum of $280 \times 10^{-4} \mathrm{~m}^{2} \mathrm{~s}^{-2}$ near $3^{\circ} \mathrm{S}$. Zonal relative maxima are separated by approximately $250 \mathrm{~km}$. Labels are in units of $10^{-4} \mathrm{~m}^{2} \mathrm{~s}^{-2}$ with a contour interval of $1.0 \times 10^{-3} \mathrm{~m}^{2} \mathrm{~s}^{-2}$.

coast, cutting through the clockwise circulations, and are absorbed into the EACC. Beginning in the summer, these eddies form west of the Seychelles at 40- to 60-day intervals through the remainder of the year. Kindle and Thompson [1989] report eddy formation in this region and in this period band in a similar model of the Indian Ocean.

A strong clockwise eddy is found throughout the year to the south of the separation of the EACC from the coast. During the SW monsoon, this eddy oscillates on a clockwise path which edges across the equator. Not all of the EACC flow recirculates in this eddy; outflow from this eddy continues northward in the Somali Current which at $4^{\circ}$ to $5^{\circ} \mathrm{N}$ reaches a peak transport of $20.5 \mathrm{~Sv}$ in August (Figure 12). This eddy is interpreted as the southern gyre of the so-called two-gyre system observed along the Somali coast during the SW monsoon [Bruce, 1973; Swallow and Fieux, 1982; Swallow et al., 1983; Schott, 1983; Luther and O'Brien, 1985; Luther et al., 1985]. Salinity observations early in the SW monsoon show the water from the EACC to recirculate south of the equator, while the equatorial currents are fed by water from north of the southem gyre [Swallow et $a l ., 1983]$. The clockwise great whirl forms between $4^{\circ}$ and $6^{\circ} \mathrm{N}$, while the southern gyre is observed south of $2^{\circ}-3^{\circ} \mathrm{N}$. The formation of the southern gyre may be caused by alongshore winds near the equator without requiring the forcing of the SE trades, as shown by McCreary and Kundu [1988], but Anderson and Moore [1979] point out that the curl of the wind near the equator can be important in determining the latitude at which the current turns offshore.

Observations show the southern gyre to leave the equator, move northward and coalesce with the great whirl in late August and September [Bruce, 1973; Brown et al., 1980; Evans and Brown, 1981; Schott, 1983). McCreary and Kund $u$ [1988] conclude from their model results that the migration of the southern gyre is due to the ocean's not being in equilibrium with peak monsoon winds. This migration has been simulated without the SE trades [Luther et al., 1985] and was seen in 14 years of a 23-year simulation forced by the winds of Cadet and Diehl [1984]. In the other 7 years, during which the southern gyre and great whirl were clearly present, the transport in the EACC was higher than that in years with migration, and a counterclockwise eddy developed north of the equator which prevented the northward
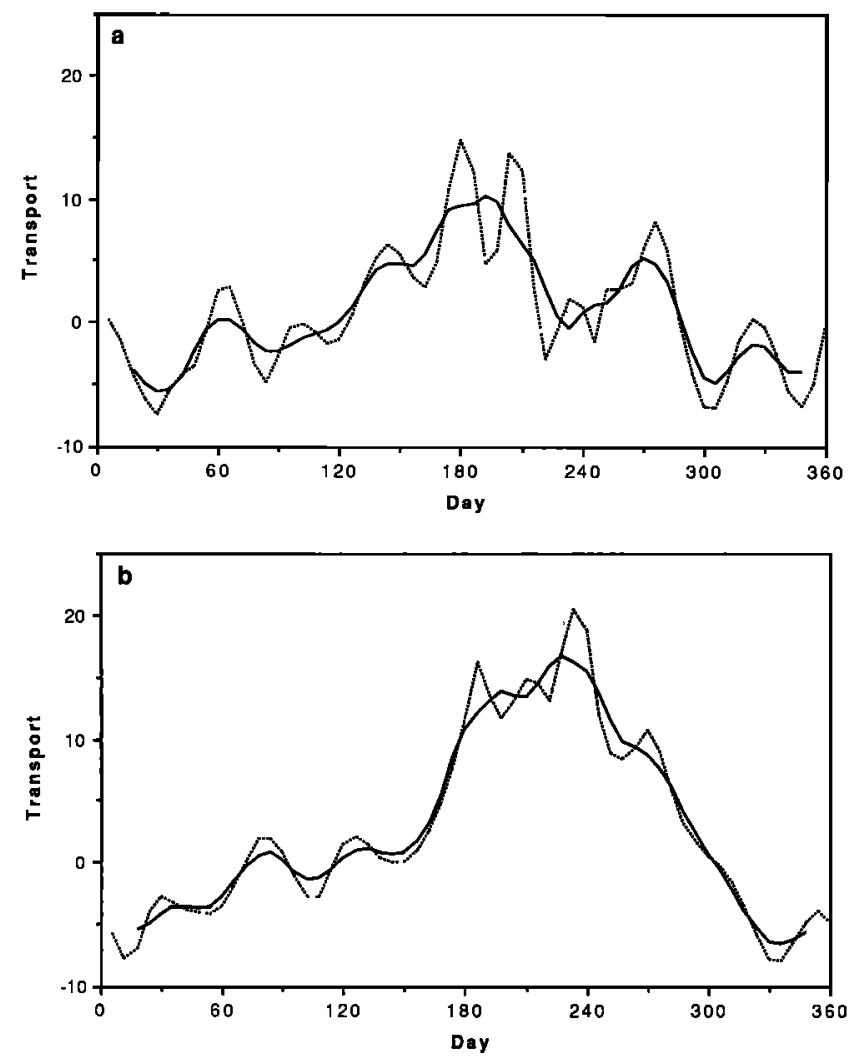

Fig. 12. Transport in the Somali Current as in Figure 4, (a) between $46.4^{\circ} \mathrm{E}, 2.6^{\circ} \mathrm{N}$ and $48^{\circ} \mathrm{E}, 1^{\circ} \mathrm{N}$ (section 7 ; mean transport is $0.8 \mathrm{~Sv}$ to the north) and (b) between $48.6^{\circ} \mathrm{E}, 5 \mathrm{~N}$ and $49.6^{\circ} \mathrm{E}, 4^{\circ} \mathrm{N}$ (section 8; mean transport is $2.6 \mathrm{~Sv}$ to the north). Dashed line is instantaneous transport computed at 6-day intervals. Solid line has been smoothed with a five-point (1 month) filter.

migration of the southern gyre. The southern hemisphere winds were anomalously strong in those 7 years, driving a stronger EACC transport; however, that simulation did not include fully the effects of the southern hemisphere trade winds, which also affect the transport in the EACC. Anderson and Moore [1979] find that the separation latitude for a cross-equatorial inertial jet moves closer to the equator as the transport of the jet increases. This is supported by the results of the 23-year simulation.

The climatological wind forcing used in this simulation favors the blocking situation. The clockwise eddy in the EACC separation moves northward as the SW monsoon winds strengthen in May and June to become the southem gyre. As it approaches the equator it has the wrong sense of rotation for the northern hemisphere. A counterclockwise eddy forms on the other side of the equator through the offshore advection of boundary layer potential vorticity around the southern gyre (Plate 2c). Both eddies are cyclonic in their respective hemispheres. The net effect of this two eddy system is that the northem eddy blocks the northward movement of the southern gyre as in the mechanism of Cox [1979]. In this model simulation, the cross-equatorial eddy pair begins to move south with the transition to the NE monsoon in October-November and southward flow across the equator is reestablished (Plate $2 d$ ).

\subsection{Equatorial Currents}

The model equatorial currents reverse four times during the year, producing the eastward equatorial jets as documented by 
Wyrtki [1973]. He noted the appearance of the jet during monsoon transitions in April-May and in SeptemberOctober with strongest flow between $60^{\circ} \mathrm{E}$ and $90^{\circ} \mathrm{E}$. O $O^{\prime} B$ rien and Hurlburt [1974] showed that these jets were transient responses to the onset of along-equator winds. Except in August, the reversals in the model equatorial currents propagate from east to west as reported from buoy trajectories by Reverdin et al. [1983] and Reverdin and Luyten [1986] and from a current meter array at $40^{\circ} \mathrm{E}$ to $62^{\circ} \mathrm{E}$ by Luyten and Roemmich [1982]. The following chronology refers to flow east of about $55^{\circ} \mathrm{E}$, away from the eddy activity near the coast. West of the Maldives and $\mathrm{Gan}\left(73.5^{\circ} \mathrm{E}\right)$, model geometry includes numerous islands which affect the flow; this area is more active in terms of eddies and oscillations. Because of these natural distinctions, the Maldive longitude will be used to split the basin into west and east for the following discussion.

In December and January the flow west of the Maldives and $G a n$ is westward with weak flow in the east. In February, weak equatorial flow is found across the basin (Plate 1). Westerly winds in March begin to drive eastward flow in the eastern basin, while outflow from the EACC into the SECC begins to move toward the equator in the west. Eastward flow is seen between $60^{\circ}$ and $80^{\circ} \mathrm{E}$ in mid-April, with weak, confused flow farther to the east. The meandering SECC is located just south of the equator to the west of $60^{\circ} \mathrm{E}$, where it remains through May. By mid-June, westward flow prevails east of $65^{\circ} \mathrm{E}$, while eastward flow is found near the western boundary, fed by the meandering outflow from the EACC. By mid-July, westward flow is seen across most of the basin, with strongest flow between $60^{\circ}$ and $80^{\circ} \mathrm{E}$. Equatorial flow becomes weak and confused by mid-August across the basin. Eastward flow begins near the westem boundary in late August and early September, again in the meandering outflow from the EACC, and progresses eastward, covering the entire equatorial region by mid-October. During this part of the year, the eastward equatorial jet forms a part of the SECC. Westward flow again appears first in the east during November and covers the basin to $55^{\circ} \mathrm{E}$ in December.

The model response in the eastern basin is asymmetrical between the northern and southern hemispheres due to the asymmetry of the Indonesian coast. The eastward jets are associated with downwelling Kelvin waves at the equator which impinge on the NW-SE slanted boundary. The reflected equatorial Rossby waves are asymmetrical and their effects on the near-eastern boundary region will be asymmetrical. In numerical experiments involving the reflection of Kelvin waves at an asymmetrical eastern boundary, the reflected Rossby waves become symmetrical as they move into the ocean interior ( $T$. Jensen, personal communication, 1988). Part of the incoming energy propagates poleward as coastal Kelvin waves which is also an asymmetric response. The southern hemisphere coastal Kelvin waves propagate out the eastern open boundary. The northern hemisphere coastal Kelvin waves follow the closed coastline of the Bay of Bengal, round the southern tip of India, and enter the Arabian Sea.

\subsection{South Equatorial Counlercurrent}

The South Equatorial Countercurrent is not seen as a continuous current across the basin in the model. Rather, it has several tributaries and is affected by the reversing equatorial currents and by the train of Rossby waves at $6^{\circ}-$ $12^{\circ} \mathrm{S}$. In the western portion of the basin, eastward return flow to the SECC meanders around the banks and islands south of about $4^{\circ} \mathrm{S}$ when equatorial flow is westward (Plate 2a). When equatorial currents are eastward, they also feed into the SECC. There are two main tributaries to the SECC. The most continuous flow is north of the Seychelles and Chagos Archipelago which feeds the SECC farther to the east near $80^{\circ} \mathrm{E}$. This tributary is stronger during the $\mathrm{SW}$ monsoon than during the NE monsoon, as it receives input from the equatorial and Arabian Sea regions during the (northern) summer months. Plate 2 shows a second tributary to the south of the Seychelles and the Chagos Archipelago. This flow feeds the SECC along the northern edge of Saya de Malha Bank and is modulated by the annual Rossby wave train. The flow from the SECC into the SEC occurs in westward migrating bands to the east of the lows associated with the annual Rossby wave train.

\subsection{Other Currents}

Although the major currents of the Indian Ocean basin are reproduced by the model, in localized regions the model circulations do not agree well with observations. Along the western Australian coast, the model produces only a weak poleward flowing Leeuwin Current [Godfrey and Ridgway, 1985; Thompson, 1984] during December through June. This feature propagates offshore as a Rossby wave and is replaced by equatorward flow in August through October. This is most likely a limitation of the model, which lacks thermodynamic forcing, throughflow from the Pacific, and vertical resolution. Studies of the Leeuwin Current have looked at the roles of thermohaline forcing [McCreary et al., 1986; Weaver and Middleton, 1989] and remote forcing by Pacific throughflow [Godfrey and Golding, 1981; Godfrey and Ridgway, 1985; Kundu and McCreary, 1986], both of which appear to play a role but are missing from this model. The model also simulates only a weak seasonally reversing South Java Current [Wyrtki, 1961] and likely misses other localized circulations as well. In all of these regions, other forcing mechanisms in addition to the wind forcing used in this study are likely of importance.

\section{DisCussion}

The southern hemisphere gyre is the response of the ocean to the mean basin-wide wind stress curl distribution and exhibits most of the features of a classical mid-latitude gyre, modified by its proximity to the equatorial waveguide and by the large seasonal variability in the wind fields. The forcing over the ocean interior is therefore an important determinant of the western boundary flow. The negative (cyclonic) wind stress curl over the interior of the southem hemisphere tropical gyre causes upward Ekman pumping, stretching vortex tubes and requiring that they move poleward to conserve potential vorticity as in classical Sverdrup dynamics. Equatorward flow at the western boundary provides for mass conservation and restoration of potential vorticity to match that of the interior flow. The recirculation region near the western boundary south of the equator, like that associated with the Gulf Stream, provides additional time in the boundary current for fluid parcels to acquire the necessary potential vorticity to reenter the interior flow.

The trade winds of the Indian Ocean are significantly different from those of the Atlantic and Pacific. The 
southern hemisphere southeasterly trades are found farther south than in the other oceans and exhibit a strong annual cycle. Trade winds are found in the northern hemisphere only during the NE monsoon, and the reversals of the monsoon winds have no counterpart in areal extent or intensity over other oceans. In comparison, the Pacific and Atlantic are relatively symmetrically forced north and south of the equator, although there is also some seasonal variability in their trades. These oceans display major trade wind-driven gyres in both hemispheres. There is a large gyre in the southern tropical Indian Ocean but no counterpart in the northern hemisphere. During the SW monsoon, this gyre extends across the equator, encompassing the flow from the SW Monsoon Current in the Arabian Sea.

\subsection{Indo-Pacific Throughflow}

At the eastern boundary of the model, the mean transport is $2 \mathrm{~Sv}$ westward into the Indian Ocean. This is the transport required by internal Indian Ocean dynamics as forced by the winds over the ocean basin. The westward direction of the observed throughflow indicates a gradient between the Pacific and Indian Ocean basins [Wyrtki, 1987] which is not simulated in this model, since the model considers the wind-forced Indian Ocean alone. Estimates from various observational studies yield an average westward throughflow of 9.2 Sv [Gordon, 1986]. Although the model underestimates the volume of the throughflow, the seasonal cycle seen in the model transport (Figure 13) is in phase with that seen in ocean general circulation models (GCM) which include both Indian and Pacific Oceans [Kindle et al., 1987; Schott et al., 1988]. Westward flow is maximum in July through September, reaching values of $8 \mathrm{~Sv}$, with minimum values of less than $0.1 \mathrm{~Sv}$ in December and January and a brief burst of eastward transport in October.

Godfrey and Golding [1981] calculate the mass transport stream function from the Sverdrup relation from the equator to $40^{\circ} \mathrm{S}$, with and without an observed value of Indo-Pacific throughflow imposed at the eastern boundary. They find that the inclusion of a throughflow from the Pacific into the Indian Ocean on the order of $10 \mathrm{~Sv}$ is essential to obtain a realistic South Equatorial Current. Without the imposition of observed flow at the eastern boundary, they find that the

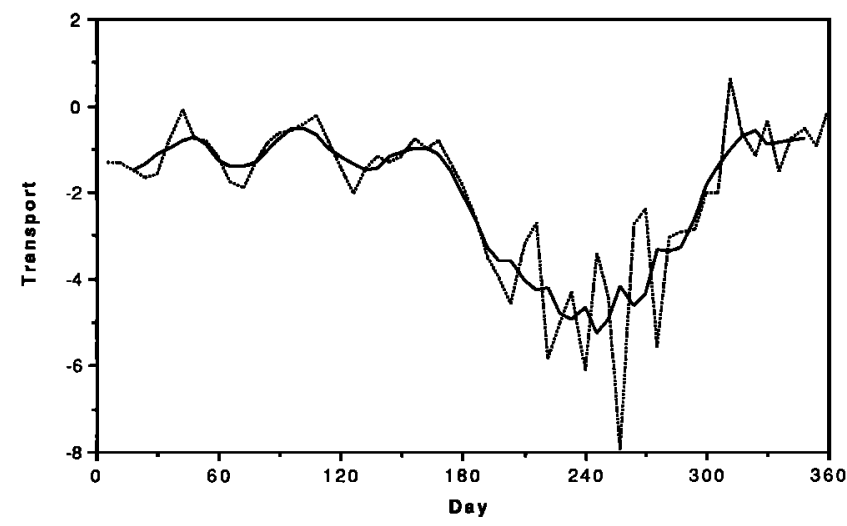

Fig. 13. Transport through the eastem open boundary across $115^{\circ} \mathrm{E}$ between $9^{\circ}$ and $20^{\circ} \mathrm{S}$ (section 1 ) as in Figure 4. Mean transport is 2 Sv to the west. Dashed line is instantaneous transport computed at 6-day intervals. Solid line has been smoothed with a five-point (1 month) filter.
Sverdrup flow is generally broad and toward the westnorthwest across the the basin from $25^{\circ} \mathrm{S}$ to $10^{\circ} \mathrm{S}$. With the throughflow imposed, the Sverdrup calculation yields a more narrow, zonal flow for the SEC, as in observed dynamic height from Wyrtki [1971]. In our model simulation, the SEC appears as a meandering, zonal current at the observed latitude, without external imposition of an Indo-Pacific throughflow. The only throughflow in the model is that of $2 \mathrm{~Sv}$ through the open boundary required by the internal Indian Ocean dynamics. The Sverdrup calculation of course ignores the time dependent component of the flow field. In fact, Godfrey and Golding [1981] attribute differences between their computed mass transport function and the observed dynamic topography to eddies in the SEC. They also attribute noise in the hydrographic data along $110^{\circ} \mathrm{E}$ to eddy activity. Their Sverdrup transport was also computed on a coarse grid ( $5^{\circ}$ in both directions). The implication here is that the structure of the SEC does not depend crucially on the imposition of an Indo-Pacific throughflow, although details of the flow in the eastern basin most likely are affected by the throughflow.

\subsection{Annual Signal}

The seasonal cycle in the southern hemisphere trades generates an annual Rossby wave in the ocean to the east of $100^{\circ} \mathrm{E}$ (Figure 4). The effects of this annual Rossby wave signal are seen in the transport of the SEC, in the flow through the eastern boundary, and in the flow patterns off northwest Australia. Although partially blocked by the Seychelles-Mauritius Ridge, this Rossby wave is responsible for the seasonal cycles in the transport of the EMC and NMC along the coast of Madagascar. An eddy formed to the east of this ridge through nonlinear interactions in the reflected Rossby wave packet breaks through the gap in the ridge as it decays, causing 70-day period oscillations at the northeast coast of Madagascar.

\subsection{0-Day Oscillations}

Several studies have noted a low-frequency variability in the currents of the western Indian Ocean. Mysak and Mertz [1984] found a 40- to 60-day oscillation in the longshore currents at the African coast between the equator and $5^{\circ} \mathrm{S}$. Quadfasel and Swallow [1986] reported 50-day oscillations in current meter records off the northern tip of Madagascar and similar oscillations in surface currents along a transect at $11^{\circ} \mathrm{S}$ west of Madagascar. It was suggested that these oceanic oscillations were being forced by the 40 - to 50 -day oscillation reported in the tropical atmosphere by Madden and Julian [1972] and found in winds over the western Indian Ocean in 1976 and 1979 by Mertz and Mysak [1984]. Current meter data reported by Schott et al. [1988] show transport variations in the 40- to 55-day period band, which accounted for over $40 \%$ of the total transport variance. The oscillations were also present in the ship measurements of Swallow et al. [1988].

In agreement with observations, but in conflict with the suggested forcing mechanism, the model fields contain oscillations in the same 40 - to 50 -day period band, even though mean monthly winds are used as forcing. The region of eddy activity to the north of Madagascar and along the east African coast is dominated by variability in the 40 - to 
50-day period band (Figures 8, 10, and 12). The EACC has especially prominent oscillations with a period of about 50 days (Figure 10). Oscillations in this period range are found in the model solutions of Kindle and Thompson [1989] and are in agreement with observations [Schott et al., 1988]. With 60 days as the shortest period resolved in the wind forcing, the model and observational variability can not be due to atmospheric forcing as has been suggested by others, since the model has no forcing at those periods. The presence of oscillations in the model response with periods shorter than 60 days requires another mechanism. These model results support the conclusions of Kindle and Thompson [1989] and of Schott et al. [1988] that the oscillations are due to internal instabilities in the ocean. Horizontal shear (barotropic) instability is the only dynamical instability mechanism in this model. The strong horizontal shears throughout the region lead to the formation of eddies through this mechanism at a period of 40 - to 50 days.

These oscillations are absent from the zonal flow in the SEC farther to the east. Sections across the SEC at $63^{\circ} \mathrm{E}$, in the gap in the Seychelles-Mauritius Ridge, and along the east coast of Madagascar show only annual and semiannual oscillations (Figures 4,5 and 7). Following the first split of the SEC at $60^{\circ} \mathrm{E}$, both the northern and southern branches of the flow contain meridional oscillations associated with the annual Rossby wave. The 70-day oscillations in the meridional transports of the EMC and in the zonal transport past Cape Amber are advective effects due to the eddy that is trapped to the east of the Seychelles-Mauritius Ridge and is shed through the gap in the ridge at $60^{\circ} \mathrm{E}, 10^{\circ}-12^{\circ} \mathrm{E}$. Kindle found transport variations with periods of 70-90 days associated with westward eddy propagation past Cape Amber [Schott et al., 1988].
It is still unclear why the period of 50 days is preferentially selected. It may be that 40 - to 50 -days is a natural period of oscillation of the system, one that is not necessarily limited to the surface currents as in the model. It is interesting to note that the core of the Equatorial Undercurrent in the Pacific oscillates about the equator with a period of about 40 days [Moore and Philander, 1977] and that 50-day oscillations are seen in the tropical Brazil Current ( $T$. Lee and $W$. Johns, personal communication, 1988). It appears that oscillations in this period band are ubiquitous in the tropical oceans. It is possible that these oceanic oscillations force those in the atmosphere, rather than the converse; indeed, Madden and Julian [1972] postulate that the 30- to 60-day atmospheric oscillations may be generated somewhere over the Indian Ocean through convection processes. We leave this for further investigations.

\subsection{8-Day Oscillations}

Linear wave theory identifies several discrete modes of oscillation at the equator [Moore and Philander, 1977]. The dispersion relation derived from the linear momentum equations has solutions which correspond to high-frequency gravity waves, low-frequency Rossby waves, equatorially trapped Kelvin waves, and the special case of mixed Rossbygravity (Yanai) waves. These mixed waves behave like Rossby waves at low frequency and like gravity waves at high frequency. Only Kelvin waves and mixed Rossbygravity waves are allowed at periods between about a week and about a month [McPhaden, 1982; Moore and McCreary, 1989].

Plate 4 shows a time-longitude section of meridional transport across the equator. Waves are generated several

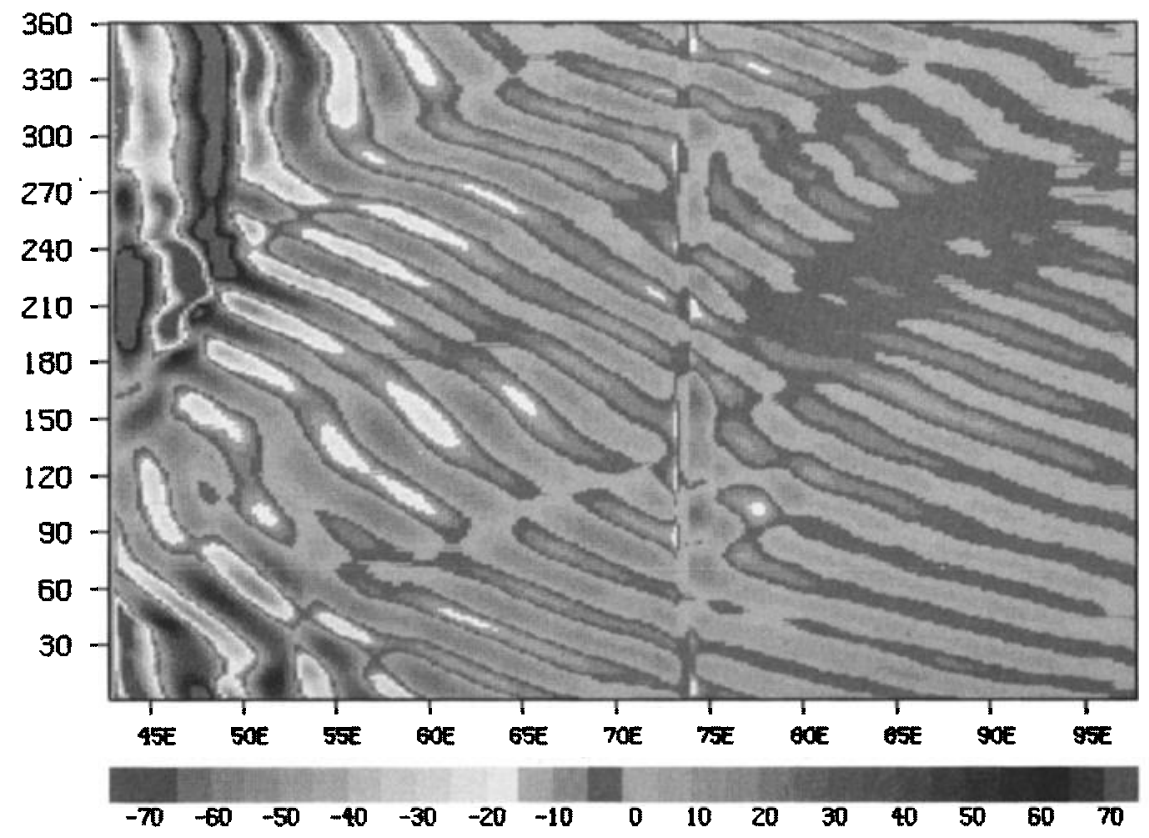

Plate 4. Time versus longitude contours of meridional transport across the equator. Time is in days after December 16, year 9. Packets of wave energy with westwand phase and eastward group propagation can be seen emanating from the westem boundary region. These waves have a period of 28 days and are interpreted as mixed Rossby-gravity (Yanai) waves generated by instabilities in the western boundary region. Transport is in sverdrups $\left(1 \mathrm{~Sv}^{2} 10^{6} \mathrm{~m}^{3} \mathrm{~s}^{-1}\right)$. Contour interval is $5 \mathrm{~Sv}$. (The color version and a complete description of this figure can be found in the separate color section in this issue.) 
times during the year near the coast out of the eddy activity which has been described there. The westward phase speed (about $20 \mathrm{~cm} \mathrm{~s}^{-1}$ ) and eastward group velocity (about $24 \mathrm{~cm}$ $\mathrm{s}^{-1}$ ) of these waves is evident. The oscillations are visible in the velocity fields of the model along the African coast and along the equator (Figure 12; Plate 2). Zonal wavelength is $500-650 \mathrm{~km}$, increasing slightly in the east. Measurements east of $60^{\circ} \mathrm{E}$ are indicative of mixed Rossbygravity waves. The waves decay eastward and are partially blocked by the Maldive Islands at $73^{\circ}-74^{\circ} \mathrm{E}$, but are seen across the basin.

The dominant period in meridional velocity at $55^{\circ} \mathrm{E}$ is found by Fourier analysis to be $\mathbf{4 0}$ to 50 days with a second peak near 28 days. West of $55^{\circ} \mathrm{E}$ the semiannual signal becomes very strong, but the same two peaks are still visible at $50^{\circ} \mathrm{E}$. The dominant period is 33 days at $60^{\circ} \mathrm{E}$ with a smaller peak near 26 days. At $65^{\circ} \mathrm{E}$ and $70^{\circ} \mathrm{E}$ there is a single peak at 28 days, suggesting a mixed Rossby-gravity wave. Luyten and Roemmich [1982] observed a dominant 26-day period in a composite meridional velocity at $200 \mathrm{~m}$ from moored current meters between $47^{\circ} \mathrm{E}$ and $62^{\circ} \mathrm{E}$. Meanders in the equatorial jet with a period of 25 days were reported from buoy trajectories by Reverdin et al. [1983] and Reverdin and Luyten [1986]. These oscillations are attributed to mixed Rossby-gravity waves. O'Neill [1984] also found characteristics of mixed Rossby-gravity waves in an array of moorings at $53^{\circ} \mathrm{E}$. O'Neill notes that incoming energy is likely to be reflected as mixed Rossby-gravity waves owing to the NE-SW angle of the African coast at the equator. Kindle and Thompson [1989] report 27-day equatorial oscillations being generated in their model by the "instability of the eastward flow" away from the coast. Moore and $\mathrm{McCreary}$ [1989] show, for the stratification of the Indian Ocean, that only Kelvin and mixed Rossby gravity waves are generated at a western equatorial boundary for periods less than 30 days, while for periods near 60 days, short Rossby waves in addition to these waves can propagate energy eastward. The present model results indicate the presence of only mixed Rossby-gravity waves at 26- to 28 day periods. The energy at $\mathbf{4 0}$ to $\mathbf{5 0}$ days appears as a result of the eddy activity to the south, as no eastward propagation of this signal is found.

\section{SUMMARY AND CONCLUSIONS}

A numerical model of the Indian Ocean, driven by the climatological monthly mean winds of Hellerman and Rosenstein [1983], simulates the major features of the largescale upper ocean circulation in the southem hemisphere and equatorial regions. Major currents (SEC, SECC, EACC, Somali Current) are found in their observed locations. Mean transports in the western basin are comparable to observations. The principal feature of the circulation in the southern hemisphere tropical Indian Ocean is a basin-wide clockwise (cyclonic) gyre comprised of the SEC in the south, the SECC to the north, and the EACC in the west. The western boundary region of this tropical gyre is a source of energetic eddy activity that is generated through shear instabilities, and it is a tropical analog of a western boundary current recirculation region of a subtropical gyre. The southern gyre of the (northern) summer Somali Current is seen as a northward extension of the western boundary current of this tropical gyre. Outflow from this region meanders eastward through various tributaries to the SECC and then into the Sverdruplike interior, where it returns to the SEC.

A Rossby wave is generated annually in the eastern basin and propagates westward in the shear zone between the SEC and SECC. The annual signal of this wave is found in branches of the SEC through the banks at $60^{\circ} \mathrm{E}$ and in the currents along the east coast of Madagscar. The SeychellesMauritius Ridge causes partial reflection of the Rossby wave, and an eddy forms due to nonlinear effects in the reflected wave packet. The eddy moves through the break in the banks early in the year and continues westward into the active western boundary region.

The seasonal cycle of the monsoons is most evident in the western boundary region and along the equator. Strong horizontal shears near the African coast between Madagascar and the equator cause the formation of clockwise and counterclockwise eddies. The Somali Current is southward during the NE monsoon, meeting the EACC and turning offshore at $2^{\circ}-3^{\circ} \mathrm{S}$. The clockwise circulation to the south of this offshore flow develops into the "southern gyre" observed during the SW monsoon when currents are northward along the coast. The gyre is blocked from its often observed northward migration by a counterclockwise eddy which forms in the northern hemisphere. The counterclockwise circulation contributes to the southward reversal of the Somali Current with the return of the NW monsoon.

Equatorial currents reverse four times annually, with westward flow found near the height of both monsoons and eastward transport found during monsoon transitions. Maximum zonal velocities are found in the westem basin with reversals starting generally in the east. Eastward equatorial currents contribute to the SECC which is fed by several tributaries around the islands in the domain.

We have noted regions where the model has some difficulty, primarily at the eastern boundary in regard to the Leeuwin Current, the Java Current, and the Pacific throughflow. Additional forcing mechanisms appear to be required for accurate modelling of these circulations. Inclusion of throughflow from the Pacific is not required in order to simulate the SEC-SECC system in agreement with its observed location.

The model results are limited by the accuracy of the wind forcing, as wind observations from the southern hemisphere are very limited. The open boundary conditions are also a problem, as flow through the boundaries is determined solely by physics interior to the model domain in a region where there is a significant input from the south and the east. The placement of the southern boundary at $25^{\circ} \mathrm{S}$ may be a factor in the simulated circulation to the east of Madagascar and in the Mozambique Channel, as no continuity of flow is allowed around the southern tip of Madagascar in the model.

It is possible to reproduce many of the large-scale features of the southem Indian Ocean with wind forcing alone. The results of this study provide encouragement for further model development. Verification of improvements will require increases in observational data, while improved models will enable better interpretation of the available data. A combined effort of modellers and observationalists is therefore required for further understanding of the circulation of the southern tropical Indian Ocean. 
Acknowledgments. The authors express their appreciation to David M. Legler, Alan C. Davis and James D. Merritt for their computational expertise, and to Rita Kuÿper for document processing assistance. Thanks also to Jon Alquist, Sharon Nicholson, Klaus Wyrtki and John Kindle, as well as two anonymous reviewers, for their insightful comments and suggestions. This work was partially supported by a NASA Traineeship in Physical Oceanography and Meteorology. Additional support was provided by the Office of Naval Research, the Institute for Naval Oceanography, and the Naval Ocean Research and Development Activity. The wind analysis is supported by the NOAA TOGA Project Office. Partial support was provided by the Florida State University through time granted on its Cyber 205 supercomputer. This is contribution number 284 of the Geophysical Fluid Dynamics Institute and number 89-100 of the Supercomputer Computations Research Institute of the Florida State University.

\section{REFERENCES}

Anderson, D. L. T., and D. W. Moore, Cross-equatorial inertial jets with special relevance to very remote forcing of the Somali Current, Deep Sea Res., 26, 1-22, 1979.

Bamett, T., Interaction of the monsoon and Pacific trade wind system at interannual time scales, I, The equatorial zone, Mon. Weather Rev., 111, 756-773, 1983.

Brown, O. B., J. G. Bruce, and R. H. Evans, Evolution of sea surface temperature in the Somali Basin during the southwest monsoon of 1979, Science, 209, 595-597, 1980.

Bruce, J. G., Large-scale variations of the Somali Current during the southwest monsoon, 1970, Deep Sea Res., 20, 837-846, 1973.

Cadet, D. L., and B. C. Diehl, Interannual variability of surface fields over the Indian Ocean during recent decades, Mon. Weather Rev., 112, 1921-1935, 1984.

Camerlengo, A. L., and J. J. O'Brien, Open boundary conditions in rotating fluids, J. Comput. Phys., 35, 12-35, 1980.

Cox, M. D., A numerical study of Somali Current eddies, J. Phys. Oceanogr., 9, 311-326, 1979.

Cutler, A. N., and J. C. Swallow, Surface currents of the Indian Ocean (to $25^{\circ} \mathrm{S}, 100^{\circ} \mathrm{E}$ ): compiled from historical data archived by the Meteorological Office, Bracknell, UK, Rep. 187, 8pp, 36 charts, Inst. of Oceanogr. Sci., Wormley, England, 1984.

Düing. W., The Monsoon Regime of the Currents in the Indian Ocean, 68 pp., East-West Center Press, Honolulu, Hawaii, 1970.

Düing, W., and F. Schott, Measurements in the source region of the Somali Current during the monsoon reversal, J. Phys. Oceanogr., $8,278-289,1978$

Evans, R. H., and O. B. Brown, Propagation of thermal fronts in the Somali Current system, Deep Sea Res., 28, 521-527, 1981.

Fine, R., Direct evidence using tritium data for throughflow from the Pacific into the Indian Ocean, Nature, 315, 478-480, 1985.

Findlater, J., Mean monthly airflow at low levels over the westem Indian Ocean, Geophys. Mem., 115, 53 pp., H. M. S. O., London, 1971.

Godfrey, J. S., and T. J. Golding, The Sverdrup relation in the Indian Ocean, and the effect of Pacific-Indian Ocean throughflow on Indian Ocean circulation and on the East Australian Current, $J$. Phys. Oceanogr., 11, 771-779, 1981.

Godfrey, J. S., and K. R. Ridgway, The large scale environment of the poleward-flowing Leeuwin Current, Western Australia: Longshore steric height gradients, wind stress and geostrophic flow, J. Phys. Oceanogr., 15, 481-495, 1985.

Gordon, A. L., Interocean exchange of thermocline water, $J$. Geophys. Res., 91, 5037-5046, 1986.

Hastenrath, S., and P. J. Lamb, Climate Atlas of the Indian Ocean, I, Surface Climate and Atmospheric Circulation, 19 pp., 97 chants, University of Wisconsin Press, Madison, 1979.

Hellerman, S., and M. Rosenstein, Nomal monthly wind stress over the world ocean with error estimates, J. Phys. Oceanogr., 13. 1093-1104, 1983.

Kindle, J. C., and J. D. Thompson, The 26- and 50-day oscillations in the westem Indian Ocean: Model results, J. Geophys. Res., 94, 4721-4736, 1989.

Kindle, J. C., G. W. Hebum, and R. C. Rhodes, An estimate of the Pacific to Indian Ocean throughflow from a global numerical model, in Further Progress in Equatorial Oceanography, edited by E. Katz and J. Witte, pp. 317-322, Nova Univiversity Press, Dania, Fla., 1987.
Knox, R. A., On a long series of measurement of Indian Ocean equatorial currents near Addu Atoll, Deep Sea Res., 23, 211-221. 1976.

Knox, R. A., The Indian Ocean: Interaction with the monsoons, in Monsoons, edited by J. Fein and P. Stephens, pp. 365-398, John Wiley, New York, 1987.

Knox, R. A., and D. L. T. Anderson, Recent advances in the study of the low-latitude ocean circulation, Prog. Oceanogr., 14, 259-318, 1985.

Kundu, P. K., and J. P. McCreary, Jr., On the dynamics of the throughflow from the Pacific into the Indian Ocean, J. Phys. Oceanogr., 16, 2191-2198, 1986.

Leetmaa, A., The response of the Somali Current to the southwest monsoon of 1970, Deep Sea Res., 20, 319-325, 1972.

Legler, D. M., I. M. Navon, and J. J. O'Brien, Objective analysis of pseudostress over the Indian Ocean using a direct-minimization approach, Mon. Weather Rev., 117, 709-720, 1989.

Luther, M. E., Indian Ocean modelling, in Further Progress in Equatorial Oceanography, edited by E. Katz and J. Witte, pp. 303316, Nova University Press, Dania, Fla., 1987.

Luther, M. E., and J. J. O'Brien, Modelling the variability in the Somali Current, in Mesoscale/Synoptic Coherent Structures in Geophysical Turbulence, edited by J. C. J. Nihoul and B. M. Jamart, pp. 373-386, Elsevier, New York, 1989.

Luther, M. E., and J. J. O'Brien, A model of the seasonal circulation in the Arabian Sea forced by observed winds, Prog. Oceanogr., 14, 353-385, 1985.

Luther, M. E., J. J. O'Brien, and A. H. Meng, Morphology of the Somali Current system during the southwest monsoon, in Coupled Ocean-Atmosphere Models, edited by J. C. J. Nihoul, Pp. 405437, Elsevier, New York, 1985.

Lutjeharms, J. R., N. D. Bang, and C. P. Dugan, Characteristics of the currents east and south of Madagascar, Deep Sea Res., 28, 879-900, 1981.

Luyten, J. R., and D. H. Roemmich, Equatorial currents at semiannual period in the Indian Ocean, J. Phys. Oceanogr., 12, 406413, 1982.

Madden, R. A., and P. R. Julian, Description of global-scale circulation cells in the tropics with a 40-50 day period, J. Atmos. Sci., 29, 1109-1123, 1972.

McCreary, J. P., and P. K. Kundu, A numerical investigation of the Somali Current during the Southwest Monsoon, J. Mar. Res., 46, 25-58, 1988

McCreary, J. P., S. R. Shetye, and P. K. Kundu, Thermohaline forcing of eastem boundary currents: With application to the circulation off the west coast of Australia, J. Mar. Res., 44, 7192, 1986. *

McPhaden, M. J., Variability in the central equatorial Indian Ocean, I, Ocean dynamics, J. Mar. Res., 40, 157-176, 1982.

Mertz, G. J., and L. A. Mysak, Evidence for a 40-60 day oscillation over the western Indian Ocean during 1976 and 1979, Mon. Weather Rev., 112, 383-386, 1984.

Moore, D. W., and J. P. McCreary, Excitation of intermediatefrequency equatorial waves at a western boundary: With application to observations from the Indian Ocean, J. Geophys. Res., in press, 1989.

Moore, D. W., and S. G. H. Philander, Modeling of the tropical oceanic circulation, in The Sea: Ideas and Observations on Progress in the Study of the Seas, vol. 6, edited by E. Goldberg, I. McCave, J. O'Brien, and J. Steele, pp. 319-361, John Wiley, New York, 1977.

Mysak, L. A., and G. J. Mertz, A 40- to 60-day oscillation in the source region of the Somali Current during 1976, J. Geophys. Res., 89, 711-715, 1984.

Nicholls, N., The Southem Oscillation and Indonesian sea surface temperatures, Mon. Weather Rev., 112, 424-432, 1984.

O'Brien, J. J., and H. E. Hurlburt, Equatorial jet in the Indian Ocean: Theory, Science, 184, 1075-1077, 1974.

O'Neill, K., Equatorial velocity profiles, I, Meridional component, $J$. Phys. Oceanogr., 14, 1829-1841, 1984.

Pedlosky, J., Geophysical Fluid Dynamics, 624 pp., SpringerVerlag, New York, 1987.

Perigaud, C., and P. Delecluse, Simulations of dynamic topography in the northwestem Indian Ocean with input of Seasat altimeter and scatterometer data, Ocean-Air Interactions, 1, 289-309, 1989.

Pickard, G. L., and W. J. Emery, Descriptive Physical Oceanography, 249 pp., Pergamon, New York, 1982. 
Piola, A. R., and A. L. Gordon, Pacific and Indian Ocean upper layer salinity budget, J. Phys. Oceanogr., 14, 747-753, 1984.

Quadfasel, D. R., and J. C. Swallow, Evidence for 50-day period planetary waves in the South Equatorial Current of the Indian Ocean, Deep Sea Res., 33, 1307-1312, 1986.

Rao, R. R. , R. L Molinari, and J. F. Festa, Evolution of the climatological near-surface thermal structure of the tropical Indian Ocean, 1, Description of mean monthly mixed layer depth, and sea surface temperature, surface current, and surface meteorological fields, J. Geophys. Res., 94, 10,801-10,816, 1989.

Reverdin, G., and J. Luyten, Near-surface meanders in the equatorial Indian Ocean, J. Phys. Oceanogr., 16, 1088-1100, 1986.

Reverdin, G., M. Fieux, and J. Luyten, Free drifting buoy measurements in the Indian Ocean equatorial jet, in Hydrodynamics of the Equatorial Ocean, edited by J. Nihoul, pp. 99-120, Elsevier, New York, 1983.

Saetre, R., and A. J. da Silva, The circulation of the Mozambique Channel, Deep Sea Res., 31, 485-508, 1984.

Schott, F., Monsoon response of the Somali Current and associated upwelling, Prog. Oceanogr., 12, 357-382, 1983.

Schott, F., M. Fieux, J. Kindle, J. Swallow, and R. Zantopp, The boundary currents east and north of Madagascar, 2, Direct measurements and model comparisons, J. Geophys. Res., 93. 4963-4974, 1988

Simmons, R. C., M. E. Luther, J. J. O'Brien, and D. M. Legler, Verification of a numerical ocean model of the Arabian Sea, $J$. Geophys. Res., 93, 15,437-15,453, 1988.

Swallow, J. C., and M. Fieux, Historical evidence for two gyres in the Somali Current, J. Mar. Res., 40, suppl., 747-755, 1982.

Swallow, J. C., R. L. Molinari, J. G. Bruce, O. B. Brown, and R. H. Evans, Development of near-surface flow patterns and water mass distribution in the Somali Basin in response to the southwest monsoon of 1979, J. Phys. Oceanogr., 13, 1398-1415, 1983.

Swallow, J. C., M. Fieux, and F. Schott, The boundary currents east and north of Madagascar, 1, Geostrophic currents and transports, J. Geophys. Res., 93, 4951-4962, 1988.

Thompson, R. O. R. Y., Observations of the Leeuwin Current off westem Australia, J. Phys. Oceanogr., 14, 623-628, 1984.

Weaver, A. J., and J. H. Middleton, On the dynamics of the Leeuwin Current, J. Phys. Oceanogr., 19, 626-648, 1989.

Wyrtki, K., Physical oceanography of the Southeast Asian waters, Scientific Results of the Maritime Investigations of the South China Sea and Gulf of Thailand 1959-1961, NAGA Rep. 2, 195 pp., Scripps Inst. of Oceanogr., La Jolla, Calif., 1961.

Wyrtki, K., Oceanographic atlas of the International Indian Ocean Expedition, 531 pp., National Science Foundation, Washington, D.C., 1971

Wyrtki, K., An equatorial jet in the Indian Ocean, Science, 181, 262-264, 1973.

Wyrtki, K., Indonesian through flow and the associated pressure gradient, J. Geophys. Res., 92, 12,941-12,946, 1987.

M. E. Luther and J. J. O'Brien, Mesoscale Air-Sea Interaction Group, Mail Stop B-174, Florida State University, Tallahassee, FL 32306

K. E. Woodberry, CATA, Box 391, University of Colorado, Boulder, CO 80309

(Received April 13, 1988; accepted July 6,1989 .) 


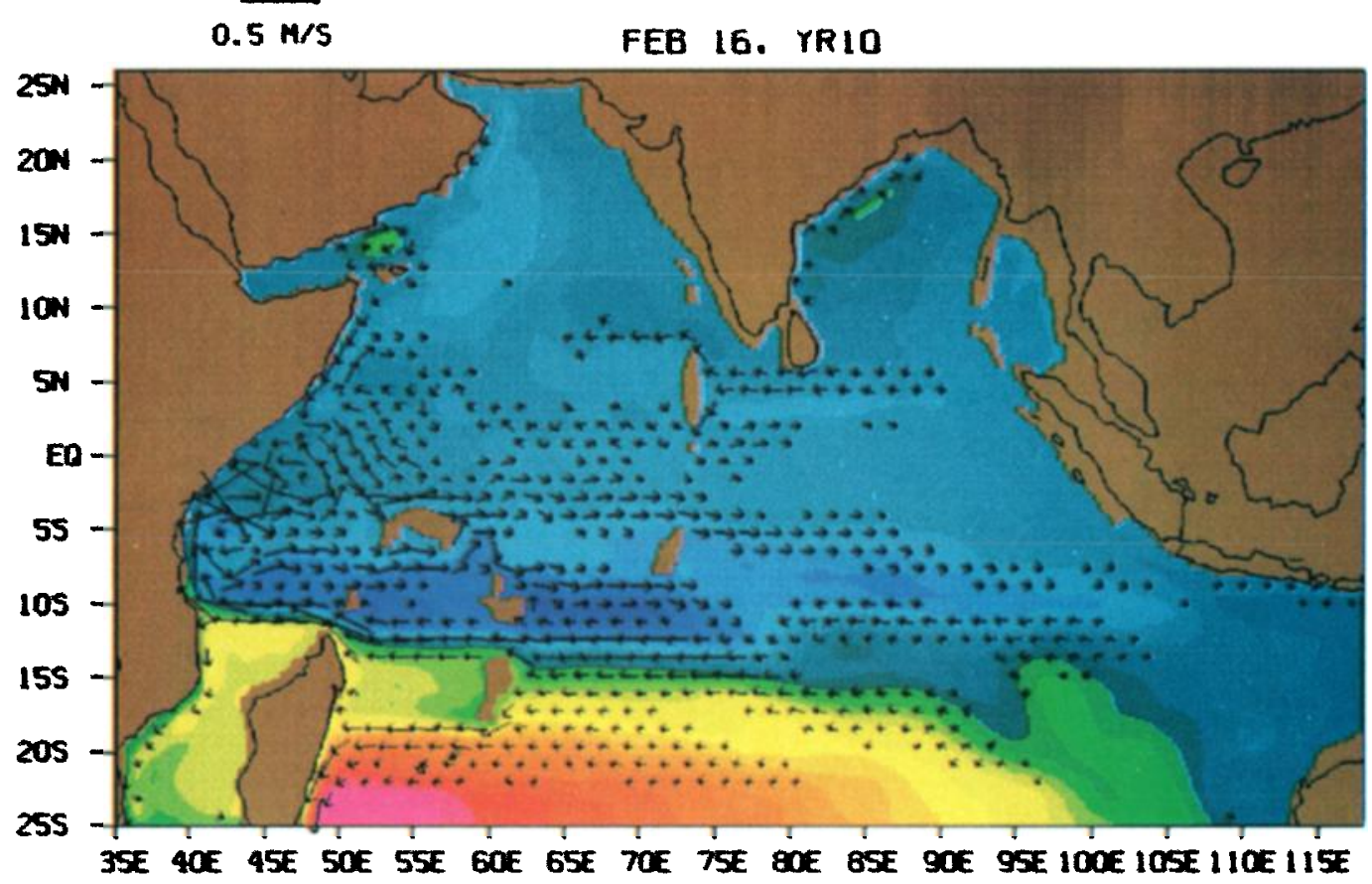

$\mathbf{a}$

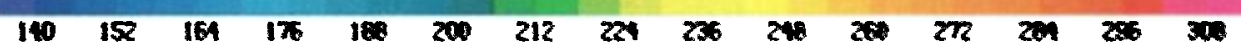

$0.5 \mathrm{~m} / \mathrm{s}$

AUG 16. YRIO

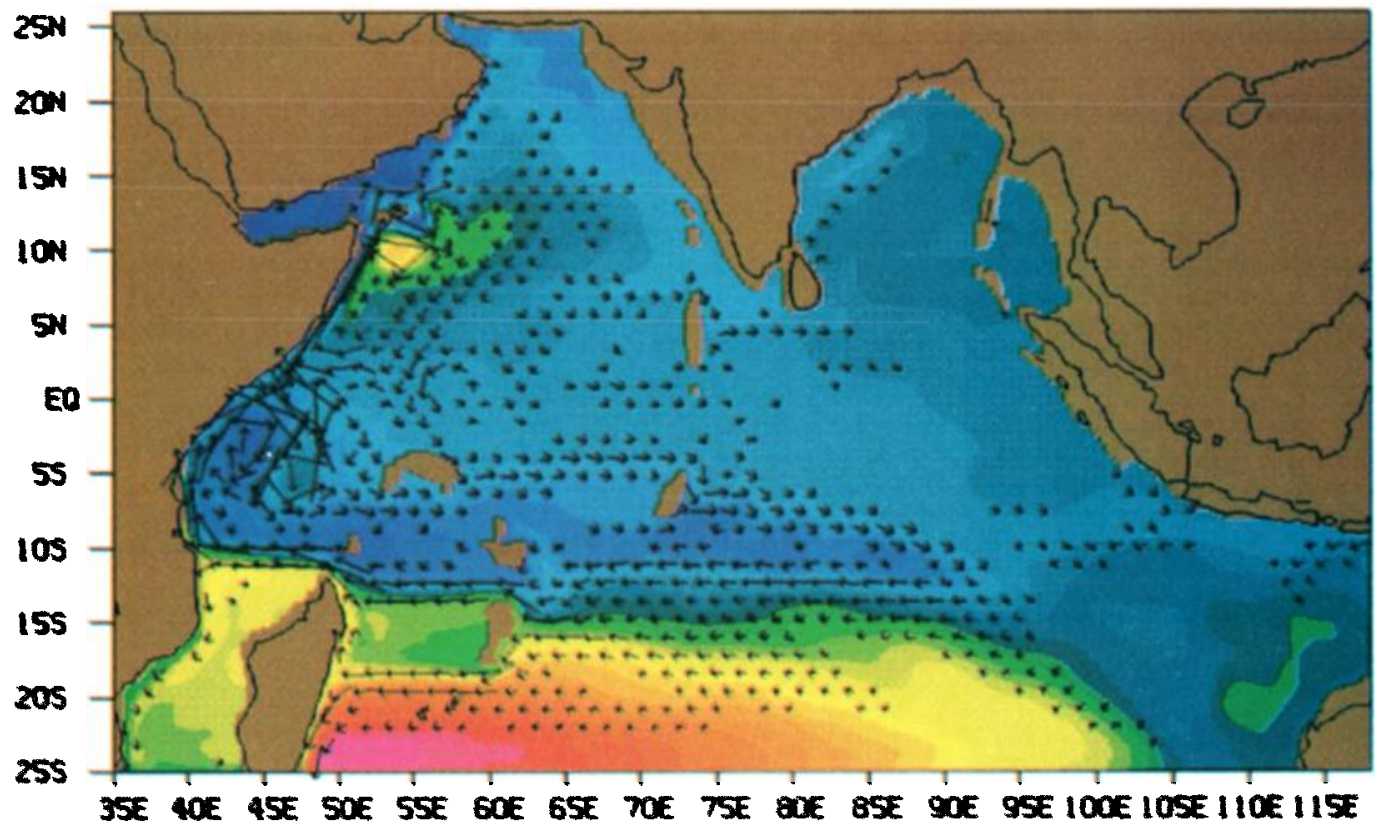

b

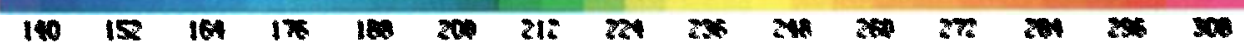

Plate 1 [Woodberry et al.]. Model upper layer thickness and velocity from the tenth year of integration. Arrows indicate upper layer velocity, with only one arrow shown each $1.6^{\circ}$ in latitude and longitude. Arrows representing velocities greater than $1.0 \mathrm{~m} \mathrm{~s}^{-1}$ are truncated, and those less than $0.05 \mathrm{~m} \mathrm{~s}^{-1}$ are supressed for clarity of display. Scale arrow is shown at upper left. Color indicates ULT value in meters, with the color scale shown at the bottom. Brown indicates land values. (a) February. (b) August. 

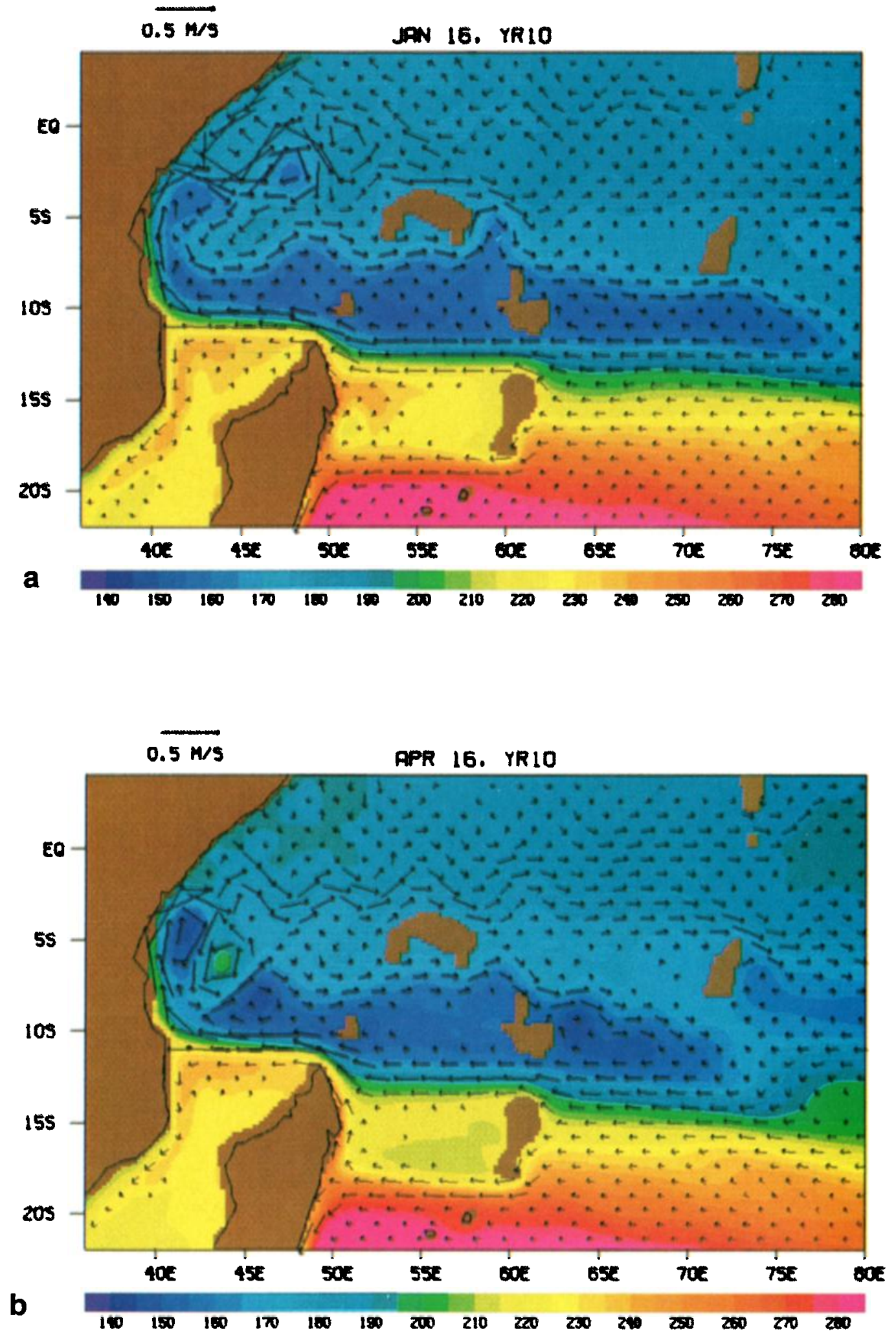

Plate 2 [Woodberry et al.]. Southwestem area of the model domain $\left(36^{\circ} \mathrm{E}\right.$ to $80^{\circ} \mathrm{E}, 22^{\circ} \mathrm{S}$ to $4^{\circ} \mathrm{N}$ ). Color and arrows are as in Plate 1. (a) January. (b) April. (c) July. (d) October. The Rossby wave between $8^{\circ}$ and $12^{\circ} \mathrm{S}$ is blocked by the Seychelles-Mauritius Ridge in January through April. An eddy forms to the east of the SMR and is advected through the gap at $11^{\circ}$ to $13^{\circ} \mathrm{S}$ in early July. Intense eddy activity is seen in the westem boundary current recirculation region to the north of Madagascar and to the west of the Seychelles throughout the year. Mixed Rossby-gravity (or Yanai) waves are particularly evident in the equatorial region during the monsoon transition months of April and October. 

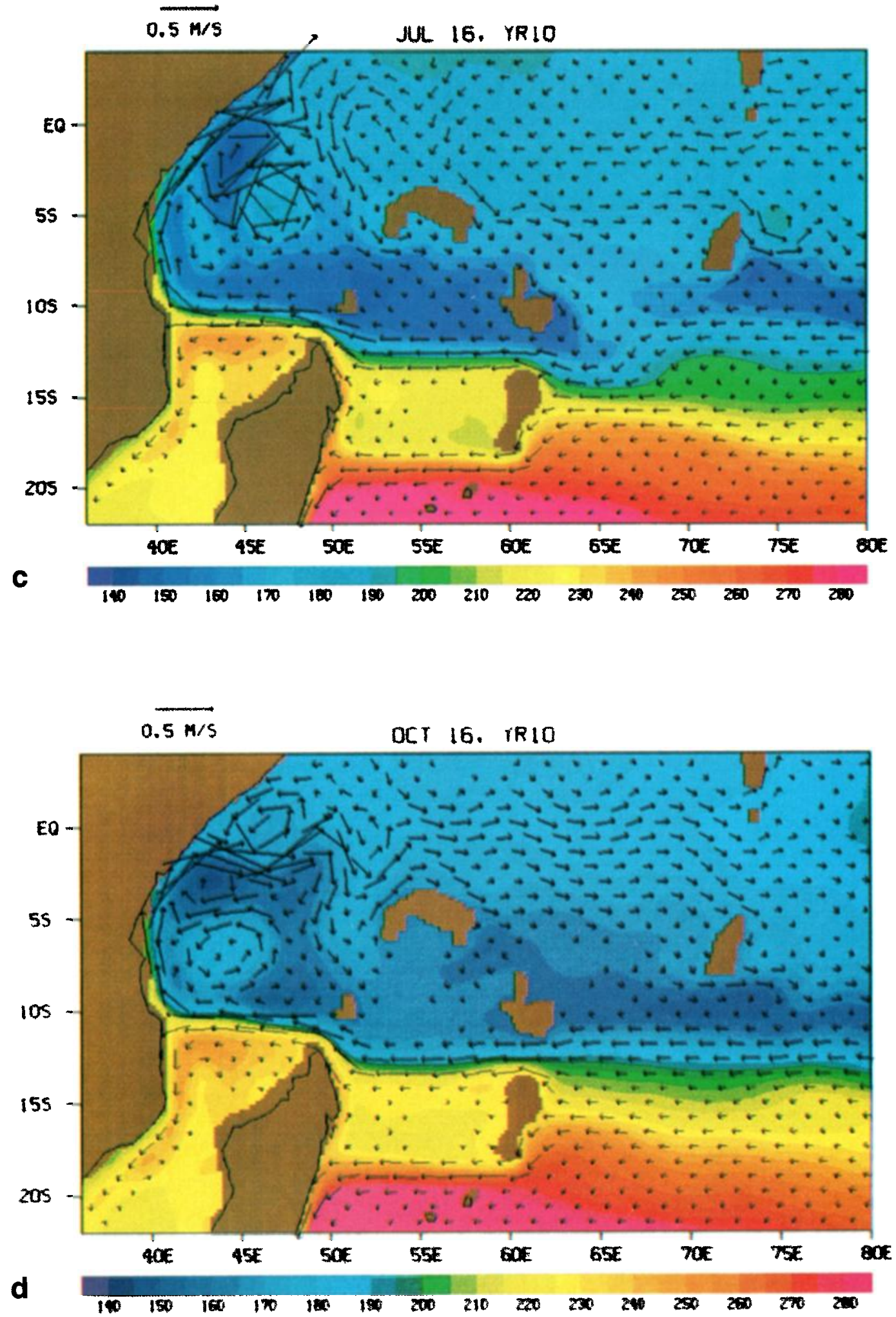

Plate 2 (continued) 


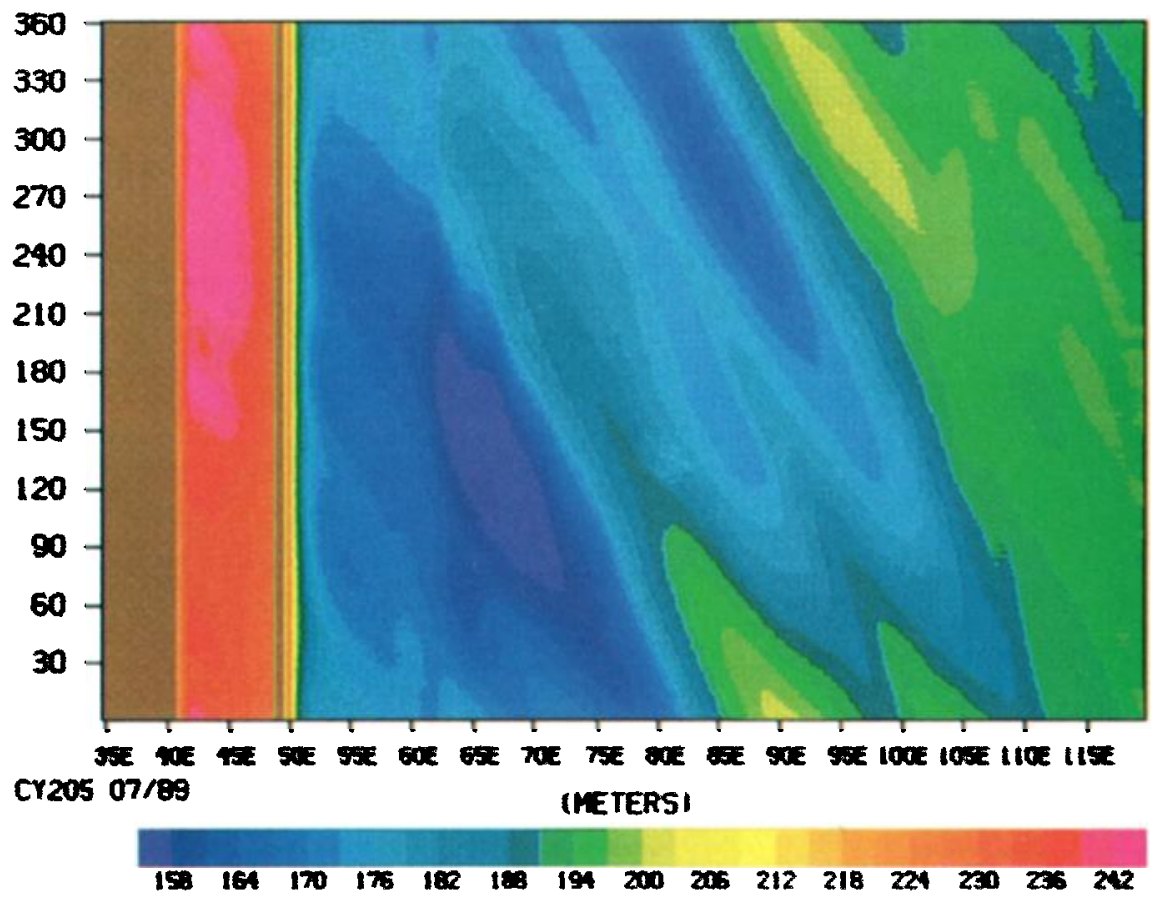

Plate 3 [Woodberry et al.]. Time versus longitude contours of model upper layer thickness (ULT) along $12^{\circ} \mathrm{S}$. Time is in days after December 16, year 9. Color indicates ULT value in meters, with the color scale shown at the bottom. Brown indicates land values. The Rossby wave generated east of $100^{\circ} \mathrm{E}$ is blocked by the Seychelles-Mauritius Ridge at $60^{\circ} \mathrm{E}$. An eddy shed through the gap in the ridge is seen to propagate westward until it is absorbed into the northward current at the east coast of Madagascar at $49^{\circ} \mathrm{E}$ (the brown vertical strip).

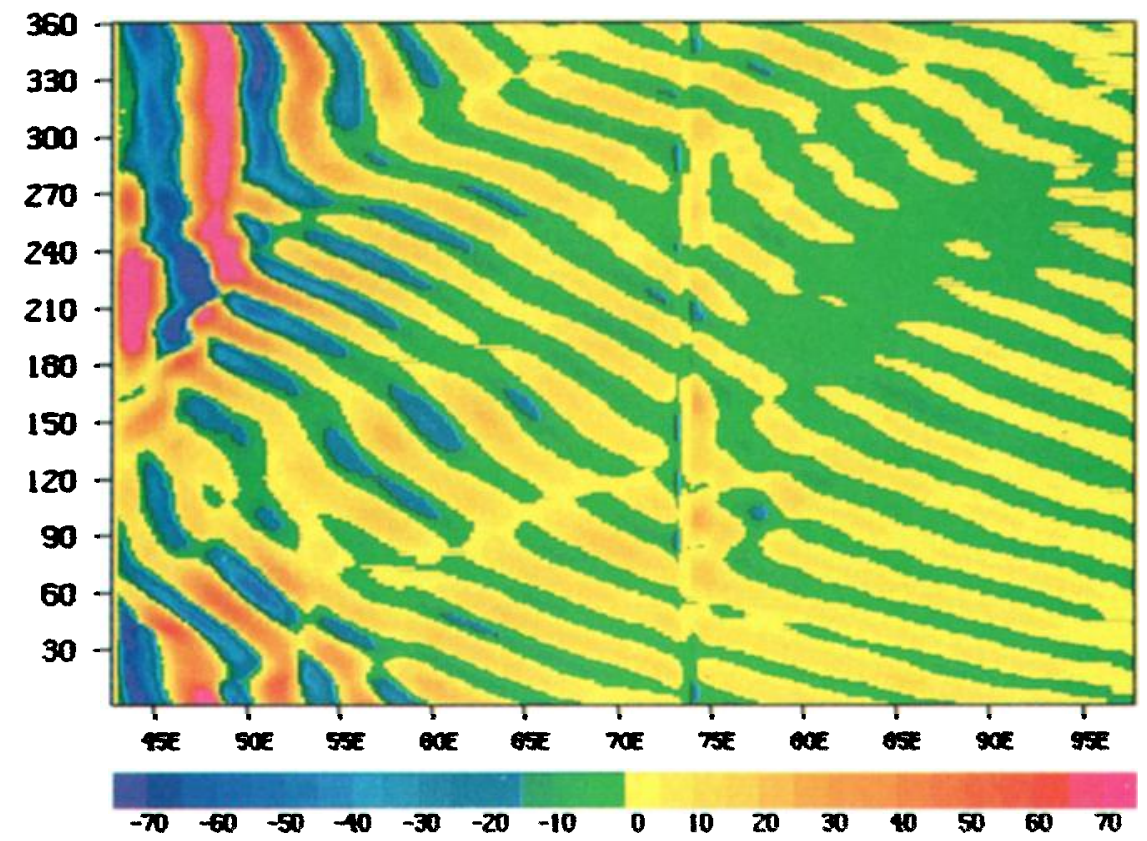

Plate 4 [Woodberry et al.]. Time versus longitude contours of meridional transport across the equator. Time is in days after December 16, year 9. Color indicates transport value, with green to red denoting northward transport and yellow to blue indicating southward transport. Brown indicates lard values. Packets of wave energy with westward phase and eastward group propagation can be seen emanating from the westem boundary region. These waves have a period of 28 days and are interpreted as mixed Rossby-gravity (Yanai) waves generated by instabilities in the western boundary region. Transport is in sverdrups ( $\left.1 \mathrm{~Sv}=10^{6} \mathrm{~m}^{3} \mathrm{~s}^{-1}\right)$. Contour interval is $5 \mathrm{~Sv}$. 